\title{
Monofacial and Bifacial Micro PV Installation as Element of Energy Transition-The Case of Poland
}

\author{
Piotr Olczak ${ }^{1, *(1)}$, Małgorzata Olek ${ }^{2}$, Dominika Matuszewska ${ }^{3}{ }^{(}$, Artur Dyczko $^{1}$ and Tomasz Mania ${ }^{4}$ \\ 1 Mineral and Energy Economy Research Institute, Polish Academy of Sciences, 7A Wybickiego St., \\ 31-261 Cracow, Poland; dyczko@min-pan.krakow.pl \\ 2 Faculty of Environmental and Energy Engineering, Cracow University of Technology, 24 Warszawska, \\ 31-155 Cracow, Poland; molek@pk.edu.pl \\ 3 Faculty of Energy and Fuels, AGH University of Science and Technology, 30 Mickiewicza Ave., \\ 30-059 Cracow, Poland; dommat@agh.edu.pl \\ 4 Department of Machines and Technical Systems, Faculty of Mechanical Engineering, UTP University of \\ Science and Technology in Bydgoszcz, Al. prof. S. Kaliskiego 7, 85-796 Bydgoszcz, Poland; \\ tomasz-mania@wp.pl \\ * Correspondence: olczak@min-pan.krakow.pl
}

check for

updates

Citation: Olczak, P.; Olek, M.; Matuszewska, D.; Dyczko, A.; Mania, T. Monofacial and Bifacial Micro PV Installation as Element of Energy Transition-The Case of Poland. Energies 2021, 14, 499. https:// doi.org/10.3390/en14020499

Received: 23 November 2020

Accepted: 14 January 2021

Published: 18 January 2021

Publisher's Note: MDPI stays neutral with regard to jurisdictional claims in published maps and institutional affiliations.

Copyright: (c) 2021 by the authors. Licensee MDPI, Basel, Switzerland. This article is an open access article distributed under the terms and conditions of the Creative Commons Attribution (CC BY) license (https:// creativecommons.org/licenses/by/ $4.0 /)$.

\begin{abstract}
The several government subsidies available in Poland contributed to an increased interest in PV installations. Installed PV capacity increased from $100 \mathrm{MW}$ in 2016 up to $2682.7 \mathrm{MW}$ in July 2020. In 2019 alone, 104,000 microinstallations (up to $50 \mathrm{kWp}$ ) were installed in Poland. The paper determines the energy gain and the associated reduction of $\mathrm{CO}_{2}$ emissions for two types of solar installation located in Poland. The monofacial solar modules with a power of $5.04 \mathrm{kWp}$ (located in Leki) and bifacial solar modules with a power of $6.1 \mathrm{kWp}$ (located in Bydgoszcz). Both installations use mono-crystalline Si-based 1st generation PV cells. With comparable insolation, a bifacial installation produces approx. $10 \%$ (for high insolation) to $28 \%$ (for low insolation) more energy than a monofacial PV installation. Avoided annual $\mathrm{CO}_{2}$ emission in relation to the installation capacity ranges from 0.58 to $0.64 \mathrm{Mg} / \mathrm{kWp}$ for monofacial and from 0.68 to $0.74 \mathrm{Mg} / \mathrm{kWp}$ for bifacial and is on average approx. $16 \%$ higher for bifacial installations. Cost-benefit analyses were made. For different electricity prices, the NPV for monofacial and bifacial was determined.
\end{abstract}

Keywords: photovoltaic; monofacial PV; bifacial PV; renewable energy source; $\mathrm{CO}_{2}$ emission; my electricity; PV; Poland; Mój Prąd

\section{Introduction}

Currently, the development of the industry and technology has resulted in increased energy demand. At the same time, society is much more aware of the decreasing fossil fuel resources and other problems caused by burning fossil fuels such as climate change, eutrophication, acid rain, greenhouse gas (GHG), mercury and other pollutant emissions, etc. [1,2]. Poland is one of countries where fossil fuels, mainly coal, is widely used to supply energy [3] and is facing the urgent need for developing a proper solution to deal with problems caused by the energy sector from environmental, technology, and economic points of view [4]. Data from KOBiZE shows that GHG emissions were 413.8 million tons of $\mathrm{CO}_{2 \mathrm{eq}}$ in Poland in 2017. Comparing to 1990 and 1988, emissions have been reduced by $12.8 \%$ and $28.3 \%$, respectively. One of the pillars of decarbonisation of Europe could be solar photovoltaic (PV) power generation [5]. In the European Union (EU), solar PV electricity generation capacity increased from $1.9 \mathrm{GW}$ in 2010 to over $133 \mathrm{GW}$ in 2019 . The year 2019 alone brought an increase in new installed capacity by $16.5 \mathrm{GW}$ in EU [6]. At the end of 2019, from the installed PV power capacity both in EU and UK, around 150 TWh of electricity could be generated (which gives around $5.2 \%$ of the final electricity demand) [7] Efficiency of solar PV system depends on the insolation, PV technology, system components 
and suitable design. The performance of PV depends on many different environmental parameters such as irradiance level, temperature, angular losses, partial shading, and soiling losses [8,9]. Currently, the biggest photovoltaic market in European countries with temperate climates is observed in Germany, Netherland or Poland [10]. For Poland, the estimated value of insolation during a year is about $1000 \mathrm{kWh} / \mathrm{m}^{2}$ [11-13] (Figure 1). In Poland PV sector is the fastest developed renewable energy source (RES) sector with the highest power growth over the past three years [14]-from $100 \mathrm{MW} / \mathrm{a}$ in 2016 up to almost $700 \mathrm{MW} / \mathrm{a}$ in 2019 and 2682.7 MW data as of October 1, 2020 [15,16]. It is estimated that by 2030, the installed capacity in PV will increase by approximately 5-7 GW, while in 2040-by approx. 10-16 GW [15,17]. Poland (after Germany, Spain, Netherlands, and France) has been in fifth place in EU in terms of establishing new PV systems capacities.

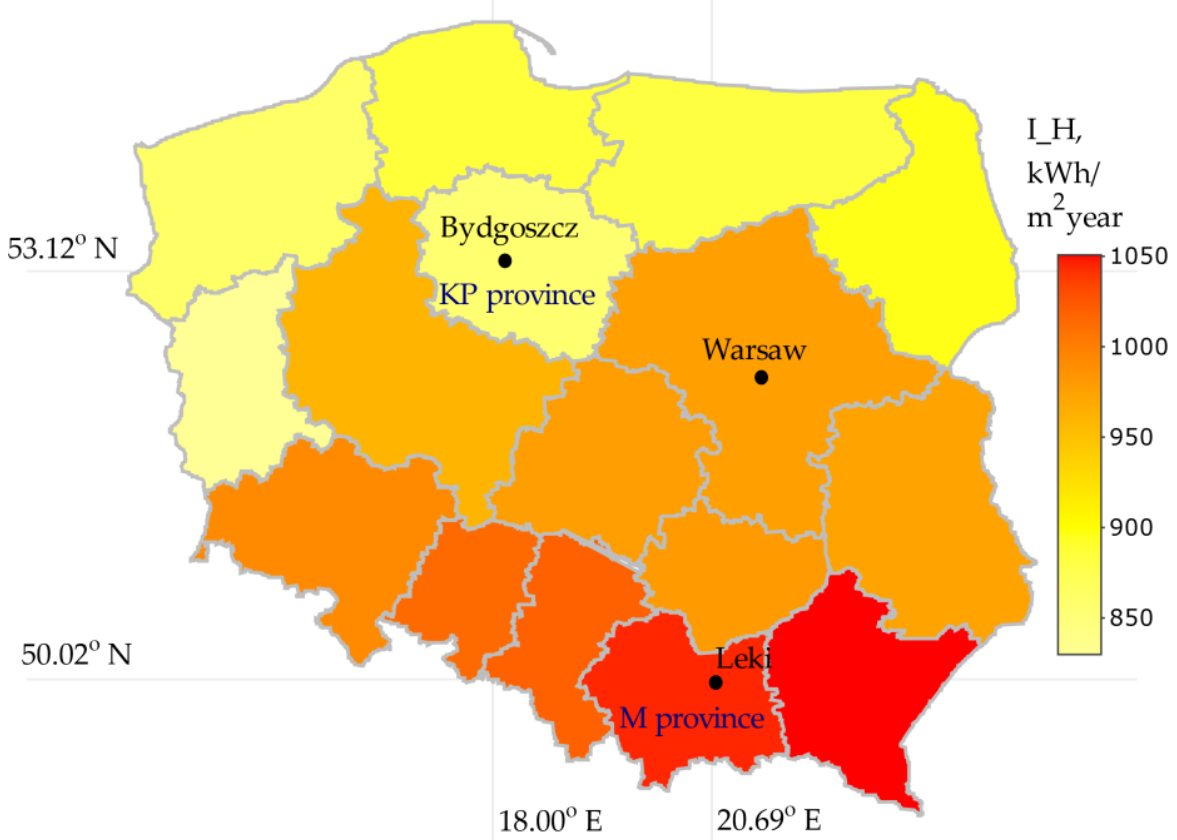

Figure 1. Yearly horizontal insolation in Poland calculated per province's capital city. KP provinceKuyavian-Pomeranian; M province-Lesser Poland. Source own study based on [18].

Jager-Waldau et al. [7] analyse the role of PV to obtain the long-term strategy of the European Commission for energy and climate change and set the target of GHG reduction from $40 \%$ to $55 \%$ by 2030 . Achieving this can make Europe the first climateneutral continent by 2050. Depending on the strategic policy scenario, reaching 55\% GHG emissions reduction would be possible if the cumulative PV capacity both in the EU and the UK surge to $455-605$ GW up to 2030.

Taking under consideration ambitious plans of 55\% GHG reduction in the EU up to 2030, it has been important to analyse the potential of micro-PV installations for reduction $\mathrm{CO}_{2}$ emission in Poland. Among the renewable energy technologies available in Poland, the greatest increase is observed in PV installations, usually microinstallations (especially up to $10 \mathrm{kWp}$ ) $[16,19]$. The reason for the increase in the number of micro-PV are subsidies in the form of government programs: "My Electricity" [14], Czyste Powietrze, Energia Plus, Prosument or Agroenergia (intended for farmers). These programs make it possible to subsidise the purchase and installation of new PV panels. In addition, the advantage of microinstallations is that annually from 25 to $30 \%$ of energy is consumed on site, and the rest of the energy can be consumed by neighbouring buildings within one microgrid (low voltage $\approx 230 \mathrm{~V}$ ). The off-grid independent PV systems are suitable and attractive for many applications for technical, economical, safety, legal reasons [20,21]. In rural areas the 
microscale installations are preferred due to their simplicity and stand-alone applications, wherein the investment in solar energy is strongly connected with the household income and wealth [22].

In contrast, the introduction of the auction support system has contributed to the development of large solar PV farms (over $1 \mathrm{MW}$ ) [23,24]. In addition, the energy price increases and PV' investment cost drops (learning curve [25]), caused the popularization of the energy prosumer business model in which company invest in PV installations for its own needs [26].

In addition, in accordance with the Polish Energy Policy, a user without a PV installation uses electricity from the energy mix [27]. This means that every hour we have a different share of sources generating electricity, including residual amounts from RES. When we install renewable energy sources and have, for example, 1 MWh of our own energy, the use of energy from the mix decreases, and because renewable energy sources have priority, we reduce energy consumption from conventional sources. So 1 MWh of renewable energy replaces $1 \mathrm{MWh}$ of nonrenewable energy, and not a mix with the current share of renewable energy [17,28], which is related to the reduction of $\mathrm{CO}_{2}$ emissions [29].

Taking under consideration the Polish conditions related to subsidies (grants per $\mathrm{kWp}$ [16]) and Prosumer rules, it is not profitable to oversize the installation [30].

In the Prosument program, under which it is possible to settle energy from RES for microinstallations, a household can receive $80 \%$ (prosumer factor $P F$ ) for $10 \mathrm{kWp}$ installation and $70 \%$ for $10 \mathrm{kWp}$ to $50 \mathrm{kWp}$ ). For example, for $1 \mathrm{kWh}$ supplied to the grid, a household can receive $0.8 \mathrm{kWh}$ (up to $10 \mathrm{kWp}$ ), or $0.7 \mathrm{kWh}$ (up to $50 \mathrm{kWp}$ ). For installations up to $10 \mathrm{kWp}$, a surplus of over $125 \%$ causes overproduction economically unprofitable for the household (the energy does not disappear in the grid, but the user gets nothing for surplus) [30,31].

Microinstallation up to $50 \mathrm{kWp}$ do not need a building permit (when the installation height does not exceed $3 \mathrm{~m}$ ), therefore the construction process is much more simplified. Microinstallations are typically installed on the roof or on ground/soil, but there is a condition that the ground should be for building purpose not for agriculture one. The paper focuses on microphotovoltaic installations located in the Kuyavian-Pomeranian and Lesser Poland province (localization-Figure 1). Characteristics of the energy production is represented by the annual values of energy sent to the grid. The amount of energy consumed from the grid is also presented [32]. Figures 2 and 3 show the performance characteristics for a selected group of installations in the Lesser Poland province.

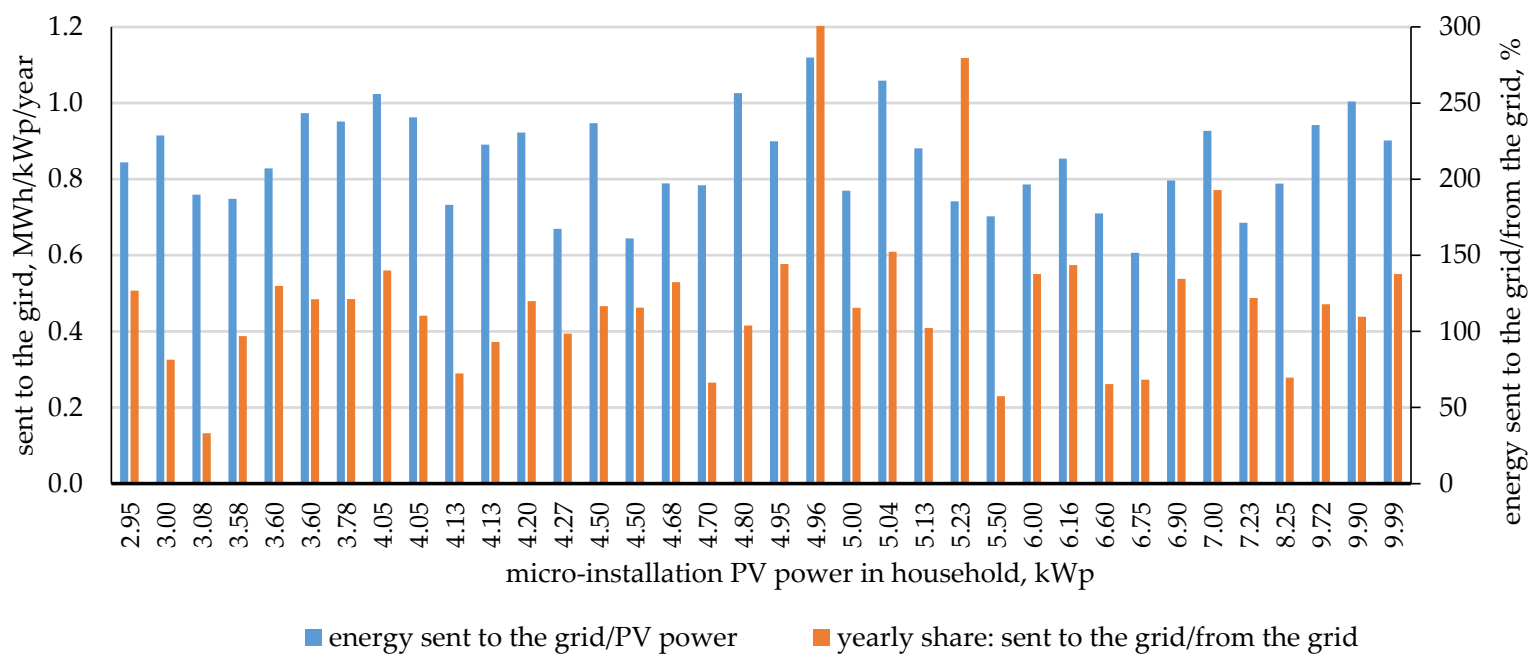

Figure 2. Annual values of energy sent to the grid in relation to the installed capacity and the annual share of energy sent to the grid in relation to the consumed, in the Lesser Poland province 1 June 2019-31 May 2020. Source own study based on [32]. 


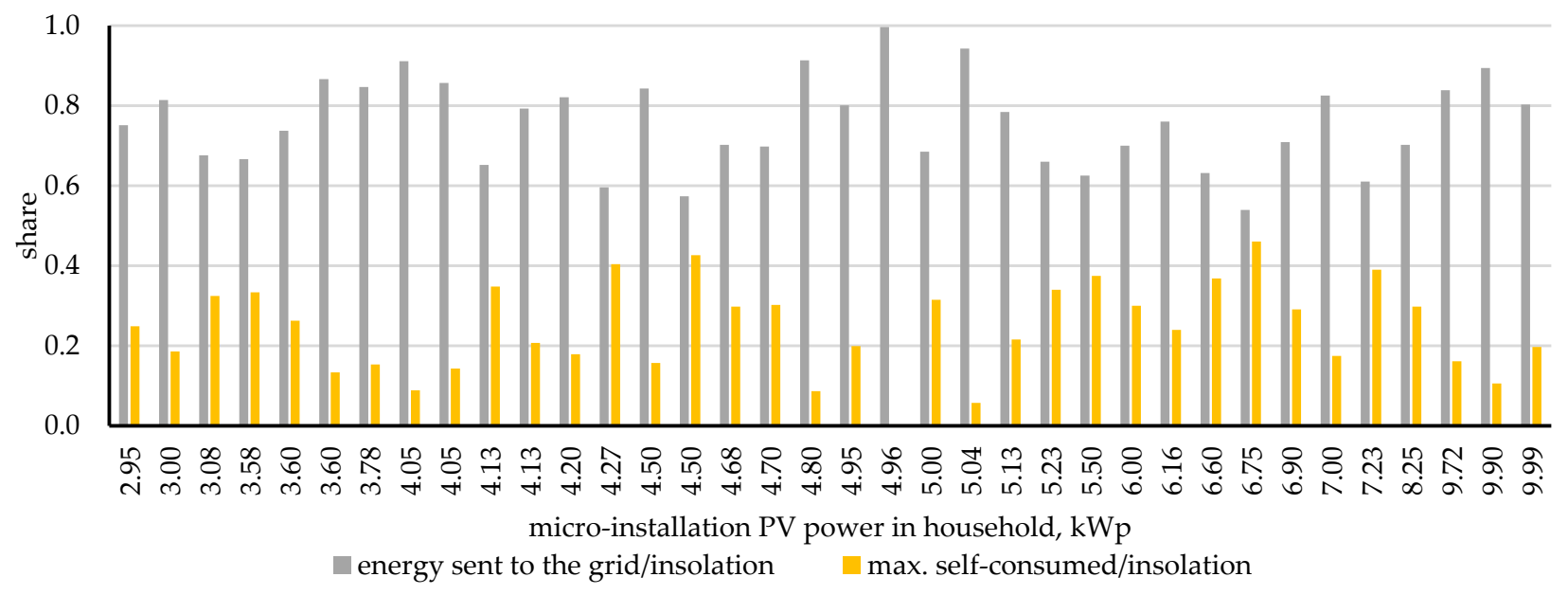

Figure 3. Annual values of energy sent to the grid in relation per $\mathrm{kWp}$ to insolation and the maximum annual self-consumed (max. self-consumed/insolation) share, in the Lesser Poland province, 1 June 2019-31 May 2020. Source own study based on [32].

Among installations with a capacity of $2.95 \mathrm{kWp}$ to $10 \mathrm{kWp}, 23$ out of 36 installations sent more energy to the grid than they consumed during the year, of which in 13 this share was greater than $125 \%$. On the other hand, one should bear in mind the ecological effects and avoided $\mathrm{CO}_{2}$ emissions. The surplus energy is sent to the grid, thus reducing the use of fossil fuels.

Based on insolation measured in Lesser Poland province (1124 kWh/m²/year [29]) and energy sent to the grid measured (Figure 2) in each installation theoretical maximum value of self-consumed energy was calculated (Figure 3) The average (for this province) maximum value of the self-consumed energy share was obtained as $24 \%$. Mean value of selected PV installation power is $5.18 \mathrm{kWp}$ but for above-mentioned the biggest grants program "My electricity" mean PV installation power value in 2019 was $5.39 \mathrm{kWp}$ (obtained for 3060 microinstallation [15]). Theoretically, the more production is sent to the network, the lower the self-consumption rate can be.

A similar analysis was performed for a selected group of installations in the KuyavianPomeranian province and shown in Figures 4 and 5.

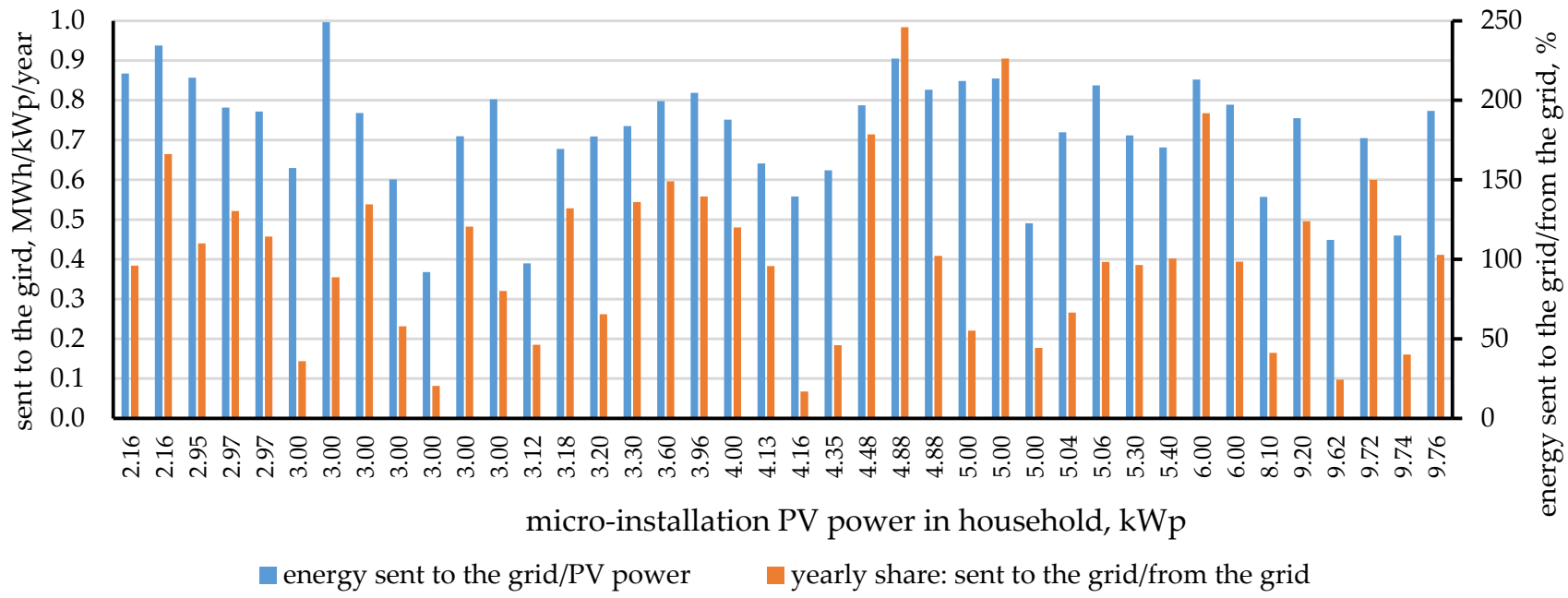

Figure 4. Annual values of energy sent to the grid in relation to the installed capacity and the annual share of energy sent to the grid in relation to the consumed, in the Kuyavian-Pomeranian province, 2019. Source: own study based on [32]. 


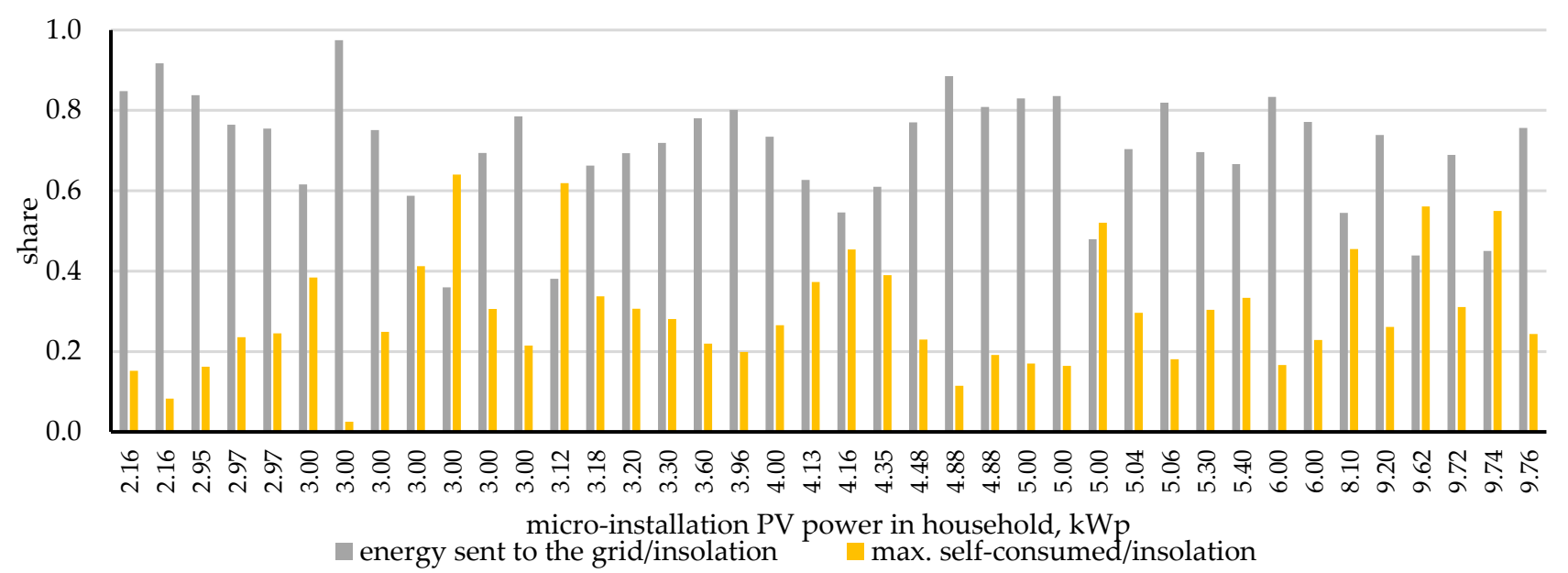

Figure 5. Annual values of energy sent to the grid in relation to insolation and the maximum annual self-consumed (max. self-consumed/insolation) share in the Kuyavian-Pomeranian province, 2019. Source own study based on [32].

In the Kuyavian-Pomeranian province 18 out of 40 installations sent more energy to the grid than they consumed during the year, of which in 12 this share was greater than $125 \%$.

Based on insolation measured in Kuyavian-Pomeranian province $\left(1022 \mathrm{kWh} / \mathrm{m}^{2} /\right.$ year [33]) and energy sent to the grid measured (Figure 4) in each installation theoretical maximum value of self-consumed energy was calculated (Figure 5) The average (for this province) maximum value of the self-consumed energy share was obtained as $30 \%$. Mean value of selected PV installation power is $4.74 \mathrm{kWp}$ but for above-mentioned the biggest grants program "My electricity" mean PV installation power value in 2019 was $5.94 \mathrm{kWp}$ (obtained for 1094 microinstallation [16]).

There are some studies considering the use of PV system to reduce $\mathrm{CO}_{2}$ emissions for example Ren at al. [34] analysed the impact of installed capacity on $\mathrm{CO}_{2}$ emissions in China, while Louwen et al. [35] analysed how 40 years of PV development influence energy sector and how contribute to GHG emissions avoidance. In Mohammadi et al. [36] research, a large-scale photovoltaic plant in southern coast of Iran has been considered. The analysis of $5 \mathrm{MW}$ installation showed that using of such system can obtain 5259 ton/year of $\mathrm{CO}_{2}$ reduction compared to the natural gas power plant. Antonanzas et al. [37] compered in their research life cycle assessment (LCA) of fixed and single axis tracking systems (SATS) for PV. A better $\mathrm{CO}_{2}$ mitigation potential has been obtained for SATS which changed between 3.4 to $14.5 \mathrm{Mg}_{\mathrm{CO} 2} / \mathrm{kW}$ compared to the fixed system for base case scenario [38,39]. Even though Prăvălie and Bandoc's research shows that PV technology is more polluting considering $\mathrm{CO}_{2}$ g per $\mathrm{kWh}$ in comparison to other energy sources technologies including wind, Concentrate Solar Power, hydro energy or nuclear energy [40]. PV technology is still preferable technology in light of carbon emission reduction in comparison to fossil fuels such as coal, oil and gas [40].

Typical installations used in Poland are systems with monofacial modules, while bifacial installations in Poland are practically nonexistent. Contrary to traditional monofacial modules, bifacial modules are assembled from cells that can effectively absorb and convert into electricity the radiation falling on both their front and back sides, which allows the use of diffused and reflected radiation (the size of which depends mainly on the albedo). According to research by Park et al. [41], depending on the albedo of the ground on which the panel is installed, the effective energy yield may be higher than $10 \%$ to $33 \%$ in relation to monofacial panels. The use of bifacial panels may cause self-consumption increase (direct) as production in the morning and evening hours is higher [42,43]. Gallegos et al. have shown that for latitudes above $40^{\circ}$, bifacial modules are more cost-effective than monofacial [44]. Based on a review of the LCA of PVs, $\mathrm{CO}_{2}$ emissions for mono-Si cells are 21 to $250 \mathrm{~g}_{\mathrm{CO} 2} / \mathrm{kWh}$, mean value by Kommalapati et al. estimated at $85 \mathrm{~g}_{\mathrm{CO} 2} / \mathrm{kWh}$. 
The large discrepancy in values depend on the energy mix at every step of the supply chain [39]. The cleaner the mix, the cleaner the solar array production. Reich et al. stated that the intensity of GHG emissions may be zero $\mathrm{g} \mathrm{CO}_{2}$-eq/ $\mathrm{kWh}$ for energy based on renewable sources and nuclear energy up to $200 \mathrm{~g}_{\mathrm{CO} 2} / \mathrm{kWh}$ for energy only from coal [45]. The current GHG footprint is around $25 \mathrm{gCO}_{2} / \mathrm{kWh}$ for mono-Si PV systems, down from 409 gCO2/kWh in 1986 [35]. There are few LCAs for bifacial modules; analysis by Gazbour et al. shows a value of $31 \mathrm{~g}_{\mathrm{CO} 2} / \mathrm{kWh}[46]$.

As shown in the paragraph above, the listed programs are not the main driving force behind the selection of bifacial PV panels. As shown on the Polish market, there is no research on the use of bifacial panels, for which a higher yield in the form of energy (from a limited area) can be achieved, and one of the goals of this work is to show how higher this yield is. Currently, due to the fact that bifacial PV panels are a newer solution than mono-facial panels (as well as less frequently used), they are more expensive, however, their popularization should affect their prices and attractiveness of use on global and Polish markets. The novelty of this paper is a comparison of a new solution for Polish climate conditions with bifacial panels to a traditional monofacial installation. Checking the economic (a profitability analysis) and ecological benefits (an assessment of the potential to avoid $\mathrm{CO}_{2}$ emissions) of using solar installations in the implemented co-financing programs for this type of projects. On the basis of the conducted research, the energy gains of both installations and the amount of $\mathrm{CO}_{2}$ emission reduction were determined. Depending on the structure of energy generation and the related $\mathrm{CO}_{2}$ emission index, the unit cost of $\mathrm{CO}_{2}$ reduction was estimated in the perspective of 20 years.

\section{Configurations of Analyzed Monofacial and Bifacial Micro PV}

Productivity analyses were carried out for two photovoltaic installations. Classic monofacial PV located in Lesser Poland with a capacity of $5.04 \mathrm{kWp}$ and bifacial PV located in Bydgoszcz with a capacity of $6.1 \mathrm{kWp}$. Both installations use mono-crystalline Si-based 1st generation PV cells. A detailed analysis was carried out for June 2020.

\subsection{PV Microinstallation in Leki (Lesser Poland Voivodship)}

The photovoltaic installation located in the Lesser Poland province (the exact geographical coordinates are shown in Figure 1) consists of 14 monocrystalline panels by Longi-Figure 6 with a power of $0.36 \mathrm{kWp}$. The technical data of the panels are included in Table 1, and the installation configuration data in Table 2 . The energy output from the inverter (Fronius $5.03 \mathrm{M}$ ) was measured every $5 \mathrm{~min}$ and the energy sent to the grid and energy from the grid was monitored via a bidirectional electricity meter.

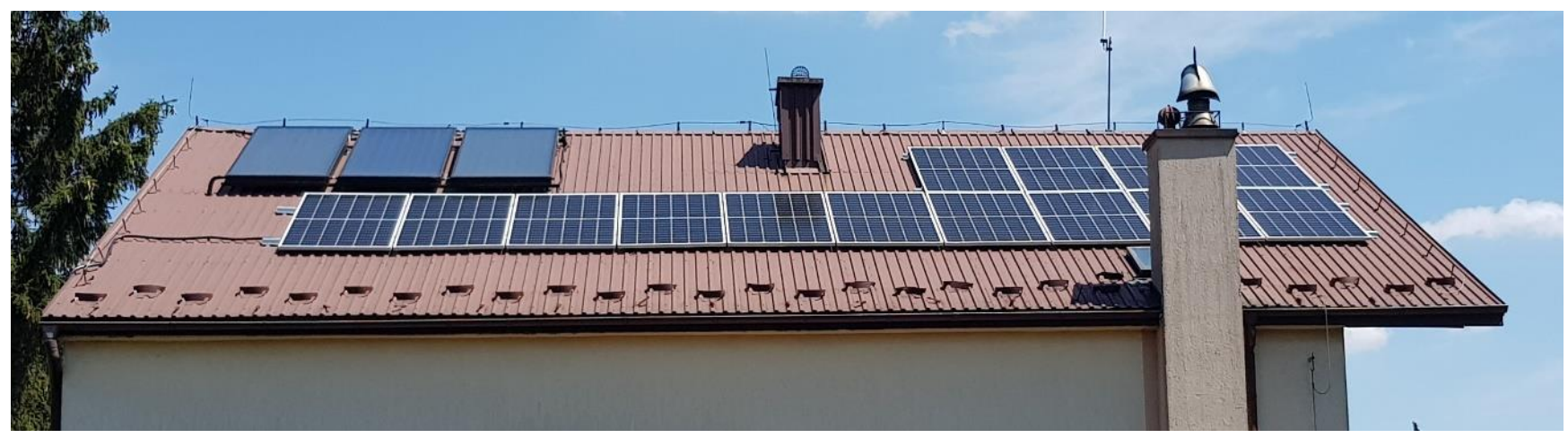

Figure 6. Panels on the roof of a single-family building in Leki.

The installation was built in 2020 at a cost of EUR 4250, of which EUR 1150 in subsidies [14,16], was obtained under the "My Electricity" program, and another EUR 250 was settled as a tax credit. The unit price without subsidies is EUR $843 / \mathrm{kWp}$, and including subsidies, it is EUR 565/kWp. 
In 2018-2019, an analysis of the demand for electricity was carried out for the building (the annual total is about $5600 \mathrm{kWh}$ ), detailed results are included in the work by Kryzia et al. [43]. The energy produced in the installation replaces energy from the electricity grid at a price of EUR $0.14 / \mathrm{kWh}$, the surplus energy produced is "virtually stored in the grid" (energy sent to the grid) and can be downloaded by the user again (up to one year) with a reduction of $20 \%$ (for installation power up to $10 \mathrm{kWp}$ ) [47].

Table 1. Characteristics of PV panels. Source: own study based on $[48,49]$.

\begin{tabular}{cccc}
\hline Parameter & Unit & Leki & Bydgoszcz \\
\hline Name & & Longi HPH 360 & BIFACIAL \\
Nominal power & $\mathrm{kWp}$ & 0.36 & 0.305 \\
Total length & $\mathrm{m}$ & 1.776 & 1.664 \\
Total width & $\mathrm{m}$ & 1.052 & 0.996 \\
$\begin{array}{c}\text { Temperature coefficient of the } \\
\text { short-circuit current }\end{array}$ & $\% /{ }^{\circ} \mathrm{C}$ & 0.057 & 0.029 \\
Temperature coefficient of the & $\% /{ }^{\circ} \mathrm{C}$ & -0.286 & -0.224 \\
$\begin{array}{c}\text { open-circuit voltage } \\
\text { Temperature coefficient of the power }\end{array}$ & $\% /{ }^{\circ} \mathrm{C}$ & -0.370 & -0.279 \\
Technology & & Mono-PERC & Bifacial, mono N \\
\hline
\end{tabular}

Table 2. Installation configuration.

\begin{tabular}{cccc}
\hline Parameter & Unit & Leki & Bydgoszcz \\
\hline Number of panels & & 14 & 20 \\
Tilt angle & $\circ$ & 30 & 45 \\
Direction & & SW & S \\
Inverter & & Fronius 5.0-3M & 2xSolar Edge SE10k \\
Power of inverters & $\mathrm{kW}$ & 5 & 6.1 \\
Total PV panel power (PI) & $\mathrm{kWp}$ & 5.04 & 6.1 \\
\hline
\end{tabular}

\subsection{PV microinstallation (Bifacial) in Bydgoszcz (Kujawsko-Pomorskie Province)}

At the UTP University of Science and Technology in Bydgoszcz, at the Faculty of Mechanical Engineering at the Institute of Manufacturing Technique, a photovoltaic installation was built (Figure 7). This installation consists of 20 Hanplast bifacial photovoltaic panels, where each panel consist of cells made in smart-wire technology with a power of $0.305 \mathrm{kWp}$. The technical data of the panels are included in Table 1 . The panels are facing south and inclined at an angle of $45^{\circ}$. They are located on the ground (meadow area), which has a positive effect on their gravity cooling compared to PV installed on the roof surface.

The modules are equipped with a P 370 type power optimiser. The entire system is protected with two SK 3K inverters with 10 PV modules connected to each of the inverters. The installation supplies teaching buildings, including server rooms, whose minimum power demand is greater than the energy production in the PV installation. All the energy produced is used on site. The installation was built at the beginning of 2020, its total cost was EUR 9800.

Detailed information about the panels is included in Table 1, and configuration data in Table 2.

The lower the values of the temperature coefficient of the open-circuit voltage and temperature coefficient of the power, the less the current efficiency of the panel depends on the panel temperature [50]. Bifacial panels are characterised by lower values. 


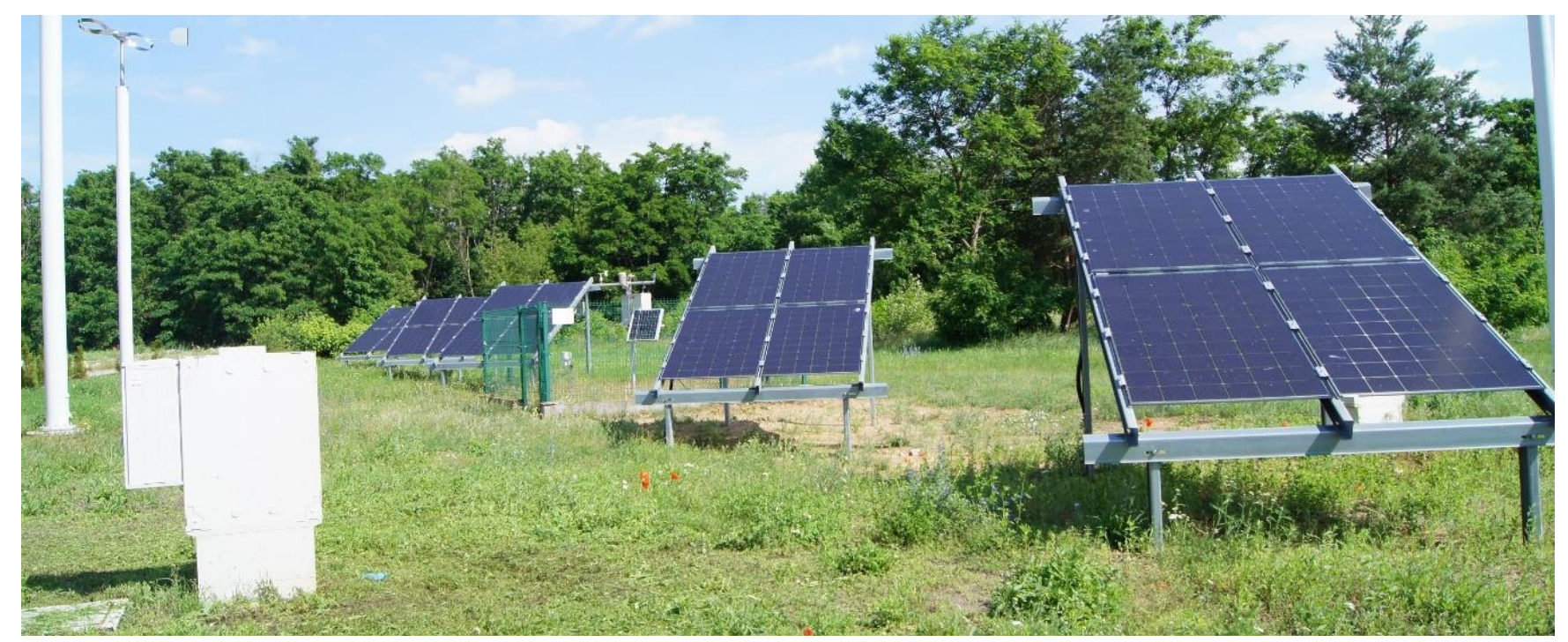

Figure 7. Setting up $5 \times 4$ panels on the ground in Bydgoszcz.

\section{Methodology of Analyses}

\subsection{Electricity Demand vs. Production}

Based on the data on the structure of production and energy consumption in the analysed buildings, the degree of coverage of the demand by PV systems was determined. Two factors have been identified: self-consumption (SC) and self-sufficiency (SS) indicators. The first could show the amount of energy produced and consumed in the same building (electric installation) with respect to total energy production in installations, at the same period of time. The self-sufficiency coefficient (SS) is the amount of energy produced and consumed in the same building (electric installation) with respect to total energy consumption in installations, at the same period of time.

$$
S C(\tau)=\operatorname{Esc}(\tau) / E p(\tau)
$$

where:

Esc - energy self-consumed from energy produced in PV installation directly in the building: energy consumption in the building minus energy from the grid

$E p$-energy produced

$\tau$-time

$$
S S(\tau)=\operatorname{Esc}(\tau) / \operatorname{Ec}(\tau)
$$

where:

Ec-energy consumption in the building $\tau$-time

\subsection{Annual Energy Gains}

Based on the measured monthly data on energy production from both installations and statistical data on insolation on a horizontal surface and for angles characteristic for the installations under consideration (Figures 8 and 9), the correction factors for multi-year analysis were determined. The method used in calculation had been based on [31,51-53]. In terms of that the following correction factors were determined: insolation coefficient (IJC), changes in insolation for a given direction and angle of panel installation (IDA), solar 
radiation conversion for the whole year (JSHIA). The following formula for annual energy gains $(E A G)$ has been proposed:

$$
E A G=\frac{1}{I J C \cdot I D A \cdot J S H I A} \cdot E M G, \frac{k W h}{\text { year }}
$$

where:

$E A G$-Annual energy gains, $\mathrm{kWh} /$ year

$E M G$-Measured monthly energy gains, $\mathrm{kWh} /$ month

IJC-Insolation coefficient, $\mathrm{kWh} / \mathrm{kWh}$, Equation (4)

$I D A-C o r r e c t i o n$ for Insolation on the direction and angle, $\mathrm{kWh} / \mathrm{kWh}$

JSHIA-Converting the insolation from June to the whole year, month/year,

$$
I J C=I \_H \_J u n e(2020) /\left(\sum_{\text {year }=2010}^{2020}\left(I \_H \_J u n e(\text { year })\right) / 11\right)
$$

I_H_June-Horizontal Insolation in June in year, $\mathrm{kWh} /\left(\mathrm{m}^{2} \cdot \mathrm{month}\right)$

$$
\begin{aligned}
& \text { IDA(direction/location) } \\
& =\left\{\begin{array}{c}
I_{-} T R Y \_S W 3 Y_{-} J u n e \text { for monofacial } \\
\text { I_TRY_S45_June for bifacial }
\end{array} \quad / I_{-} T R Y_{-} H_{-} J u n e\right.
\end{aligned}
$$

where:

I_TRY_H_June-Insolation for Typical Reference Year-Horizontal Surface, $\mathrm{kWh} /\left(\mathrm{m}^{2} \cdot \mathrm{month}\right)$ I_TRY_S45_June-Insolation for Typical Reference Year-south directed surface titled $45^{\circ}$, $\mathrm{kWh} /\left(\mathrm{m}^{2} \cdot \mathrm{month}\right)$

TRY_SW30_June-Insolation for Typical Reference Year-south-west directed surface titled $30^{\circ}[18], \mathrm{kWh} /\left(\mathrm{m}^{2} \cdot \mathrm{month}\right)$

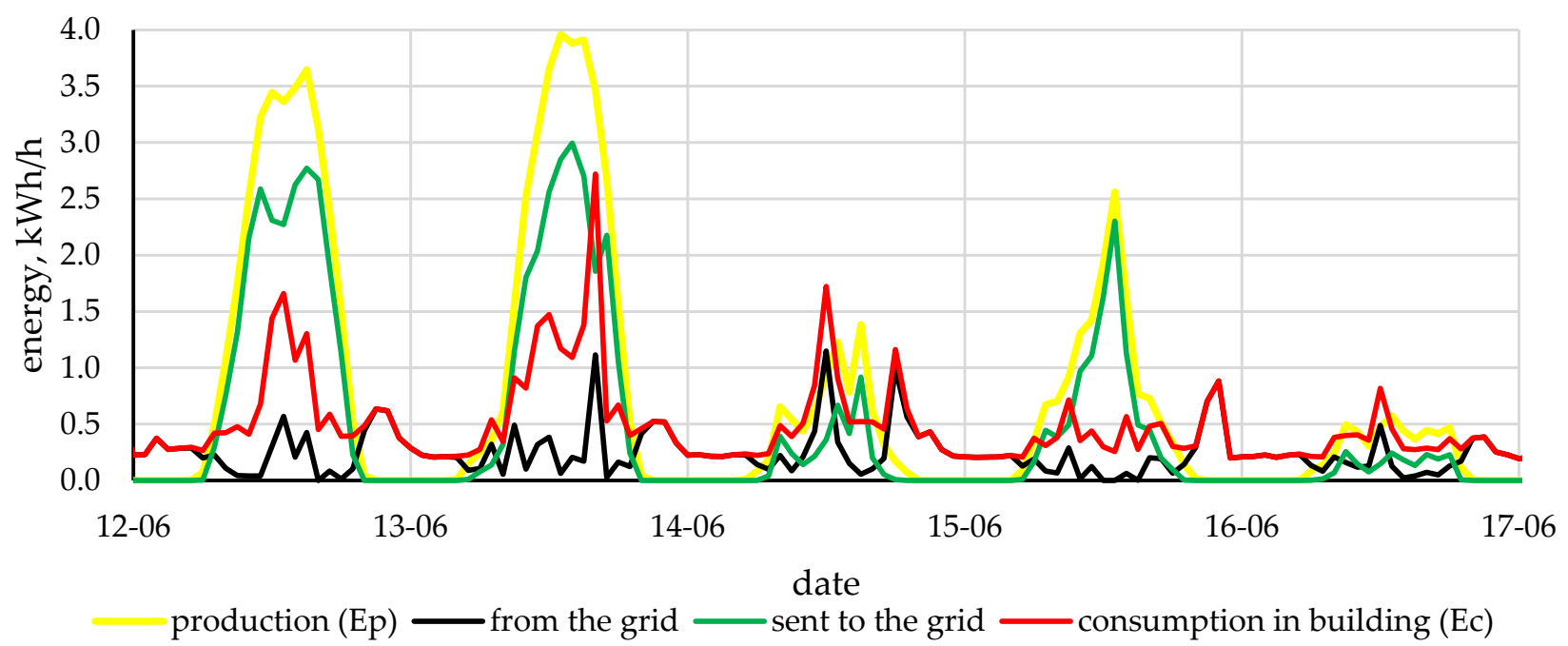

Figure 8. Energy production in the PV installation Leki and energy: added to the grid, consumed and Energy consumption in the building, June 2020. 


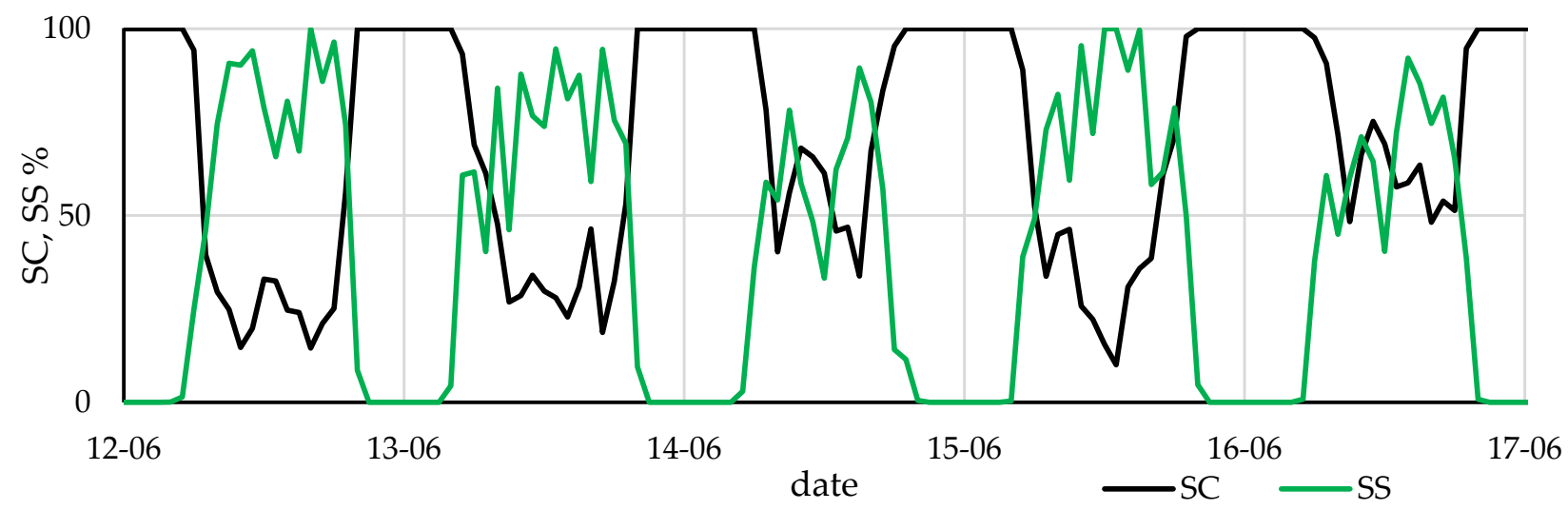

Figure 9. Self-consumption coefficient (SC) and self-sufficiency coefficient (SS) for several days of June 2020.

Based on the insolation data from 2010-2020 [33], the representativeness of insolation data for the analysed June 2020 (JSHI) was determined:

$$
J S H I=I \_H \_J u n e / I \_H \_Y e a r
$$

where:

I_H_June-Horizontal Insolation in June, $\mathrm{kWh} /\left(\mathrm{m}^{2} \cdot \mathrm{month}\right)$

I_H_Year-Horizontal Insolation in whole year, $\mathrm{kWh} /\left(\mathrm{m}^{2}\right.$.year $)$

JSHIA-is average (from 2010 to 2019 year) for value for JSHI, month/year

\subsection{Reduce of $\mathrm{CO}_{2}$ Emission}

The main reason for the construction of $\mathrm{PV}$ installations is the ability to reduce greenhouse gas emissions. The analysis considered two factors, the benefit of reducing $\mathrm{CO}_{2}$ emissions from the combustion of fossil fuels $\left(\mathrm{EECO}_{2}\right)$ and $\mathrm{CO}_{2}$ emissions that arise during the production cycle of $\mathrm{PV}$ panels $\left(\mathrm{EPVCO}_{2}\right)$ [54].

In Poland, the $\mathrm{CO}_{2}$ emission factor per $\mathrm{kWh}$ for end users of electricity (according to KOBiZE) is $0.765 \mathrm{~kg}_{\mathrm{CO} 2} / \mathrm{kWh}[3,28]$. Since the emission factor depends on the type of fuel (brown coal, hard coal) the analysis of $E E C \mathrm{O}_{2}$ has been carried out for a range of $0.4-1 \mathrm{~kg}_{\mathrm{CO} 2} / \mathrm{kWh}$. It has been assumed that during PV production the $E P V C \mathrm{O}_{2}$ changes in the range of $20-85 \mathrm{~g}_{\mathrm{CO} 2} / \mathrm{kWh}$.

$$
A C \mathrm{O}_{2}=E A G \cdot\left(E \mathrm{CCO}_{2}-E P V C \mathrm{O}_{2}\right)
$$

$\mathrm{ACO}_{2}$ - the amount of $\mathrm{CO}_{2}$ emission avoided, $\mathrm{Mg}$ /year

$E A G-$ Annual energy gains, $\mathrm{kWh} /$ year

$E E \mathrm{CO}_{2}$ - energy electricity emission factor in Poland, $\mathrm{kg}_{\mathrm{CO} 2} / \mathrm{kWh}$

$E P V C \mathrm{O}_{2}-\mathrm{CO}_{2}$ emission factor for $\mathrm{PV}, \mathrm{kg}_{\mathrm{CO} 2} / \mathrm{kWh}$

Additionally, the indicator unit (investment) cost of $\mathrm{CO}_{2}$ emission reduction factor $\left.(\mathrm{UCPVCO})_{2}\right)$ was calculated. The analysis was related to the 20 years of use of the investment and included the total installation costs (I0): Leki-EUR 4250, Bydgoszcz-EUR 9800.

$$
\mathrm{UCPVCO}=\frac{I 0}{n \cdot A C \mathrm{O}_{2}}
$$

where:

$U C P V C \mathrm{CO}_{2}$ - Unit (investment) cost of $\mathrm{CO}_{2}$ emission reduction factor, $\mathrm{EUR} / \mathrm{kgCO}_{2}$ I0-initial investment value, EUR,

$n$-lifetime of PV, year 


\subsection{Profitability Analyses}

The purpose of the economic analysis was to compare the economic results using Net Present Value (NPV) (Equation (9)).

Moreover, it was assumed:

- Discount rate $(r)$, varies in range from 0 to 0.06 [55],

- Electricity price $(E l P)$ from 0.1 to $0.2 \mathrm{EUR} / \mathrm{kWh}[43,56]$ (in 2020, ElP = $0.15 \mathrm{EUR} / \mathrm{kWh}$ ),

- Decrease in the PV panels productivity by $0.5 \%$ per year

$$
N P V(E l P, r)=\left[\sum_{t=1}^{n} \frac{C F_{t}}{(1+r)^{t}}\right]-I 0
$$

where:

$C F_{t}$ is the cash flow in the year $\mathrm{t}$, EUR (Equation (10)),

$t$-year of the analysis,

$r$-discount rate, $\%$

$$
C F_{t}(E l P)=E A G \cdot S C \cdot E l P+P F \cdot E A G \cdot(1-S C) \cdot E l P-O C
$$

where:

$C F_{t}$ is the cash flow in the year $\mathrm{t}, \mathrm{EUR}$,

$O C$ - operating cost, EUR/year,

$P F$ - prosumer factor,

ElP_electricity price, EUR/kWh,

$S C$ - self-consumption, Equation (1)

For the Leki installation, which was covered by the subsidy program, the cost of reducing $\mathrm{CO}_{2}$ emissions was calculated for the options with and without subsidies. For Bydgoszcz, the analysis was compared to the cost invested in the installation.

Additionally, NPV differences were calculated for different ElP values and for different $r$ values:

$$
\text { diff.NPV }(E l P, r)=N P V(E l P, r) \text { for Leki-NPV }(E l P, r) \text { for Bydgoszcz }
$$

\section{Results and Discussion}

\subsection{Electricity Demand vs. Production}

Figure 8 presents the details of the energy production, flow and consumption in the building Leki for selected days with high and low energy production.

For the data presented in Figure 8, self-consumption (SC) and self-sufficiency (SS) indicators were determined.

High production was achieved on the 13 June and it was $32.22 \mathrm{kWh}$ of which $21.98 \mathrm{kWh}$ were sent to the grid. Consumption on the analysed day was $16.95 \mathrm{kWh}$, of which $6.71 \mathrm{kWh}$ were obtained from the grid. For comparison, on June 14th, it was $8.04 \mathrm{kWh}$ of which $3.65 \mathrm{kWh}$ were sent to the grid. The consumption on that day was $11.91 \mathrm{kWh}$, of which $7.52 \mathrm{kWh}$ were obtained from the grid.

The SC and SS coefficients were determined for 12-17 June, the obtained results are presented in Figure 9. Then the SC and SS were determined for all hours of June-Figure 10.

For various conditions that were observed from 12 June to 17 June, it was found that only for $4 \mathrm{~h}$ the SS value was 100\%, it means that the PV installation fully covered the energy consumption only through $4 \mathrm{~h}$. In whole June, it was, only for $31 \mathrm{~h}$. The SC coefficient decreases with increasing productivity and is close to $100 \%$ only for low PV powers below $10 \%$ of nominal power, observed at low intensity of solar radiation (see Figures 8 and 9). The SS behaves the opposite (Figure 10). In the analysed period (June 2020 ), the average SC value was $30.4 \%$ and the SS was $48.9 \%$.

For bifacial installation, the energy produced by the system is used in the University buildings. The SC ratio is $100 \%$. 


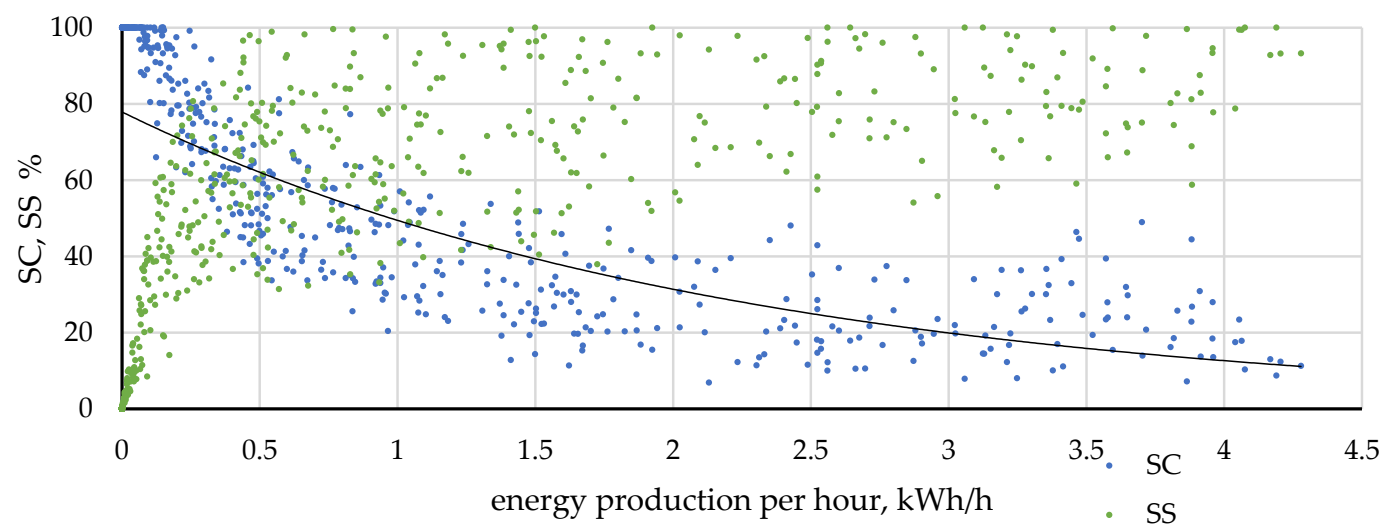

Figure 10. Self-consumption coefficient (SC) and self-sufficiency coefficient (SS) as a function of energy production per hour. June 2020.

\subsection{Anually Gain}

The amount of energy produced by the Leki installation in the form of daily sums is presented in Figure 11. The daily production of monofacial PV installation varied from $4 \mathrm{kWh}$ to $32.5 \mathrm{kWh}$. In total, $583.87 \mathrm{kWh}(E M G)$ was achieved in the period under examination.

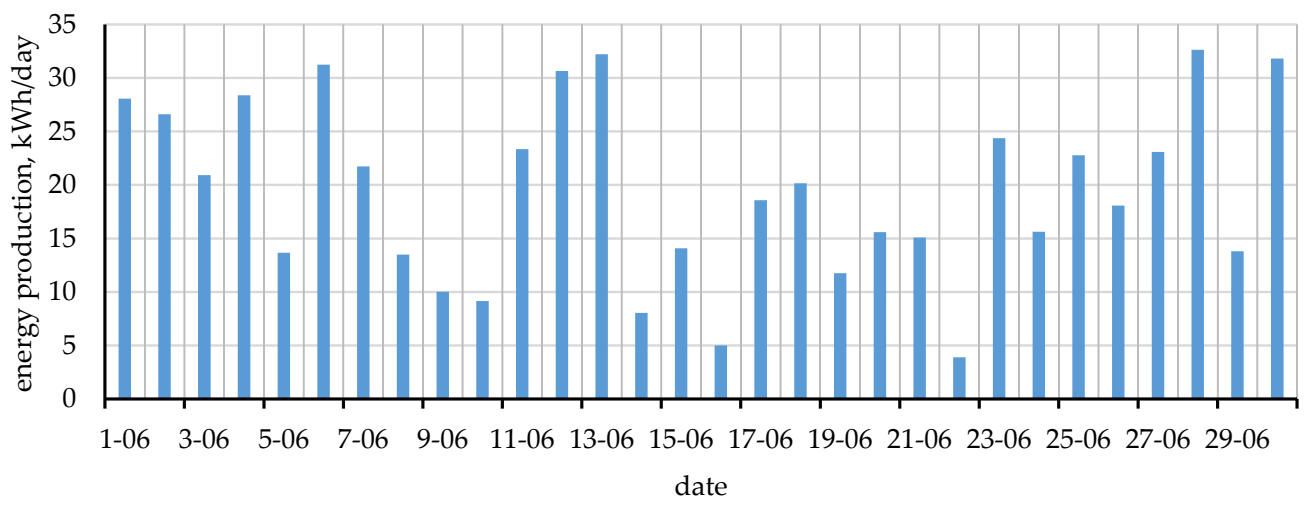

Figure 11. Daily energy production in PV installation (Leki), June 2020.

The daily production of bifacial PV installation in Bydgoszcz in June 2020 ranged from $6.4 \mathrm{kWh}$ to $46 \mathrm{kWh}$ (Figure 12). Total production for June was measured as $828.13 \mathrm{kWh}$ (EMG).

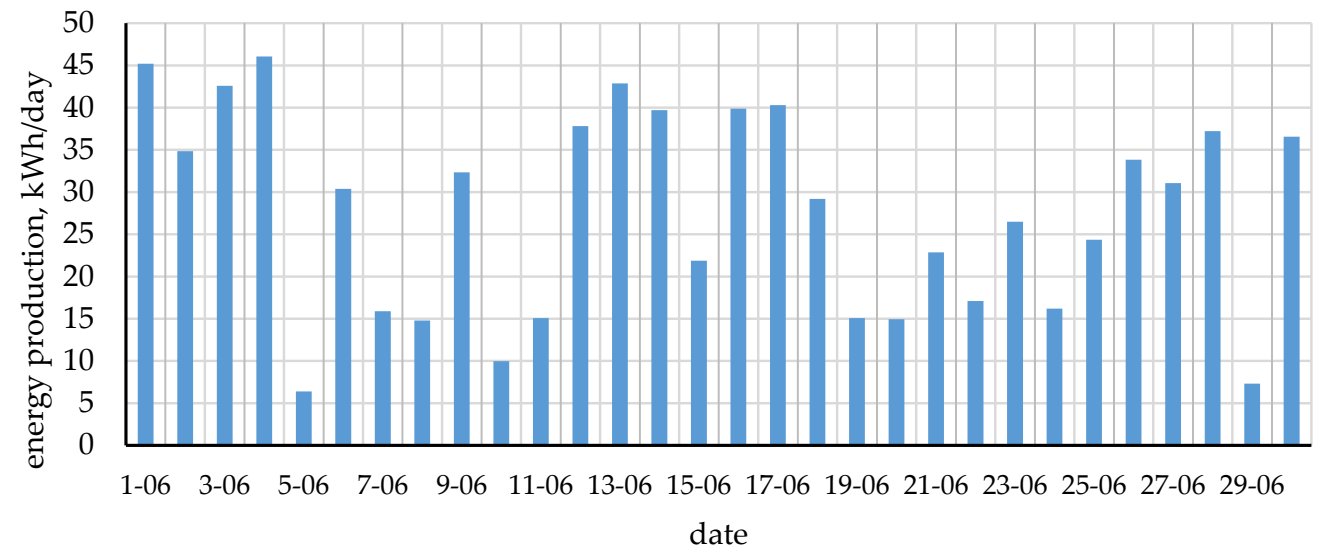

Figure 12. Daily energy production in PV installation (Bydgoszcz), June 2020. 
The recorded insolation values for each June in 2010-2020 for both locations are presented in Figure 13.

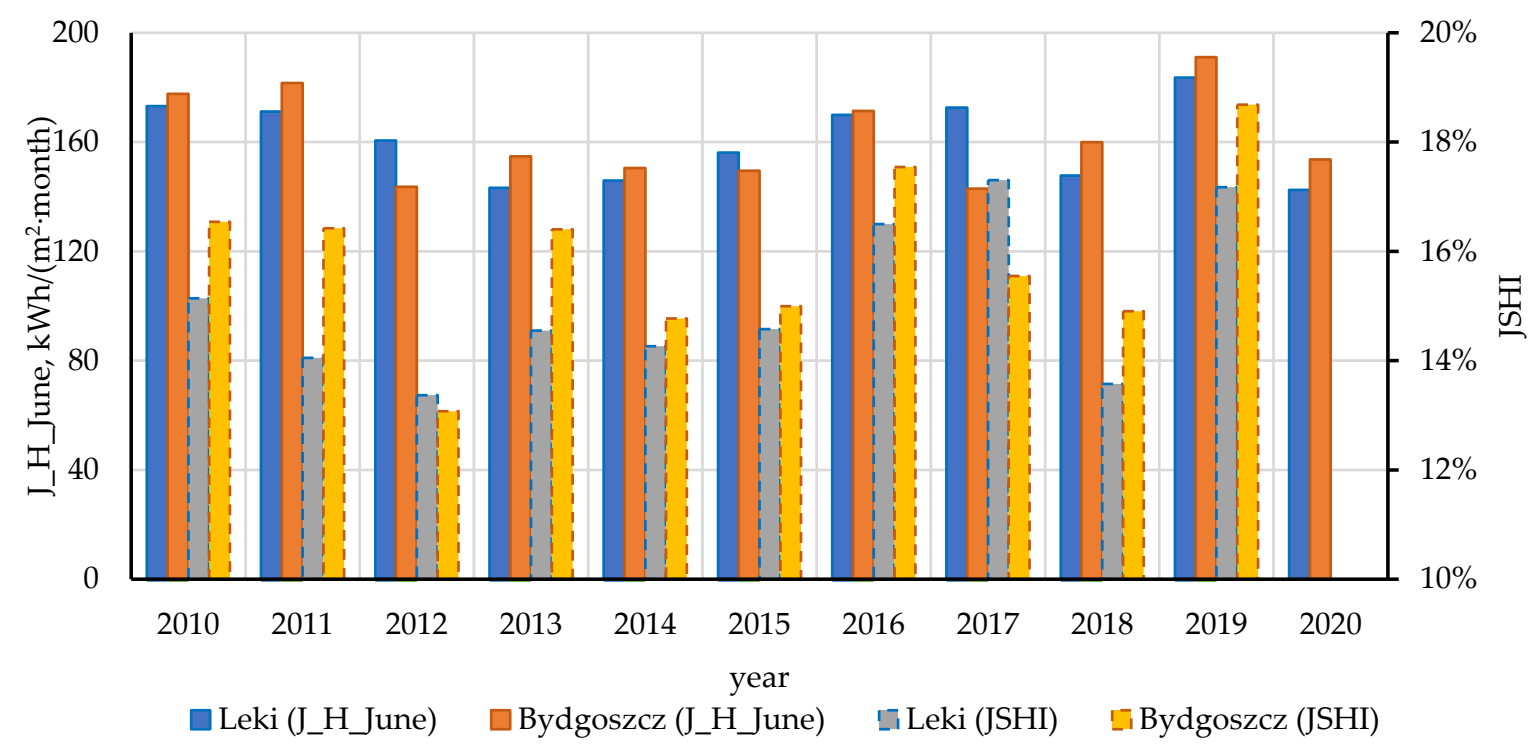

Figure 13. Comparison of insolation values varied from locations for June in the last 11 years. Source own study based on $[18,33,57]$.

In 2010-2020, the value of insolation in June for Leki varied from $145 \mathrm{kWh} /\left(\mathrm{m}^{2} \cdot \mathrm{month}\right)$ to $184 \mathrm{kWh} /\left(\mathrm{m}^{2} \cdot \mathrm{month}\right)$, and for Bydgoszcz from $144 \mathrm{kWh} /\left(\mathrm{m}^{2} \cdot \mathrm{month}\right)$ to $191 \mathrm{kWh} /\left(\mathrm{m}^{2} \cdot \mathrm{month}\right)$. The value of insolation for Leki and Bydgoszcz in June 2020 was $142.45 \mathrm{kWh}$ and $153.63 \mathrm{kWh}$ (see also Figure 15) and was lower than the 11-year average by $11 \%$ and $5 \%$. For further calculations it was assumed that the insolation coefficient IJC for the installation Leki and Bydgoszcz was 0.89 and 0.95 , respectively.

On the basis of NASA Larc data [33], the average share of registered sunlight falling on the horizontal surface for June was determined for both locations in relation to the annual amount (TRY_H). The solar representativity for the south (TRY_S45) and south-west (TRY_SW30) direction was also determined, referring to the percentage of insolation for June in the year (Typical Reference Year)-Figure 14.

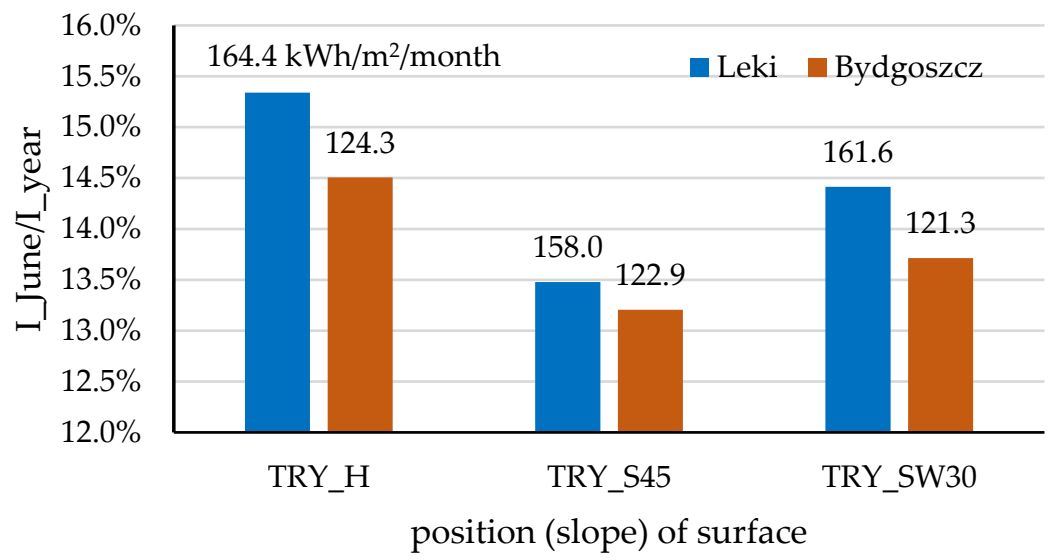

Figure 14. Comparison of the insolation values for both locations for June against the Typical Reference Year data and different location of the surface. (TRY_H-Typical Reference Year-Horizontal Surface, TRY_S45-Typical Reference Year-south directed surface titled 45 ${ }^{\circ}$, TRY_SW30-Typical Reference Year-south-west directed surface titled $30^{\circ}$ [18]. 
The average share of the registered insolation in June in relation to the annual value was $15 \%$ and $15.9 \%$ (Figure 13) and was lower by 0.3 percent point (Leki) and higher by 1.4 percent point (Bydgoszcz) compared to the Typical Reference Year (Figure 11). Taking into account the direction of the panels' installation, the insolation value for Leki differs by $0.9 \%$ compared to the Typical Reference Year-horizontal, while for Bydgoszcz by $1.2 \%$ compared to the Typical Reference Year-horizontal. For further calculations it was assumed that the insolation on the direction and angle coefficient (IDA) for the Leki and Bydgoszcz installations is 0.991 and 0.988 , respectively.

Taking into account the coefficients IJC, IDA, JSHIA (Table 3) for both locations, the annual energy gain (EAG) for Leki and Bydgoszcz was calculated as $4300 \mathrm{kWh}, 6091 \mathrm{kWh}$.

Table 3. Energy production correction factors and annual energy gains.

\begin{tabular}{cccc}
\hline Parameter & Unit & Leki & Bydgoszcz \\
\hline Monthly energy gains, EMG & $\mathrm{kWh}$ & 583.87 & 828.13 \\
Insolation coefficient, IJC & - & 0.89 & 0.95 \\
Insolation on the direction and angle, IDA & - & 0.991 & 0.988 \\
Converting the insolation from June to the & - & 0.154 & 0.145 \\
whole year, JSHIA & $\mathrm{kWh}$ & 4300 & 6091 \\
Annual energy gains, EAG & $\mathrm{kWh} / \mathrm{kWp}$ & 853 & 999 \\
Annual energy gains per PI, EAG/PI & & & \\
\hline
\end{tabular}

\subsection{Comparison of Solar Energy Production}

The value of insolation in June 2020 for both locations is shown in Figure 15 [33].

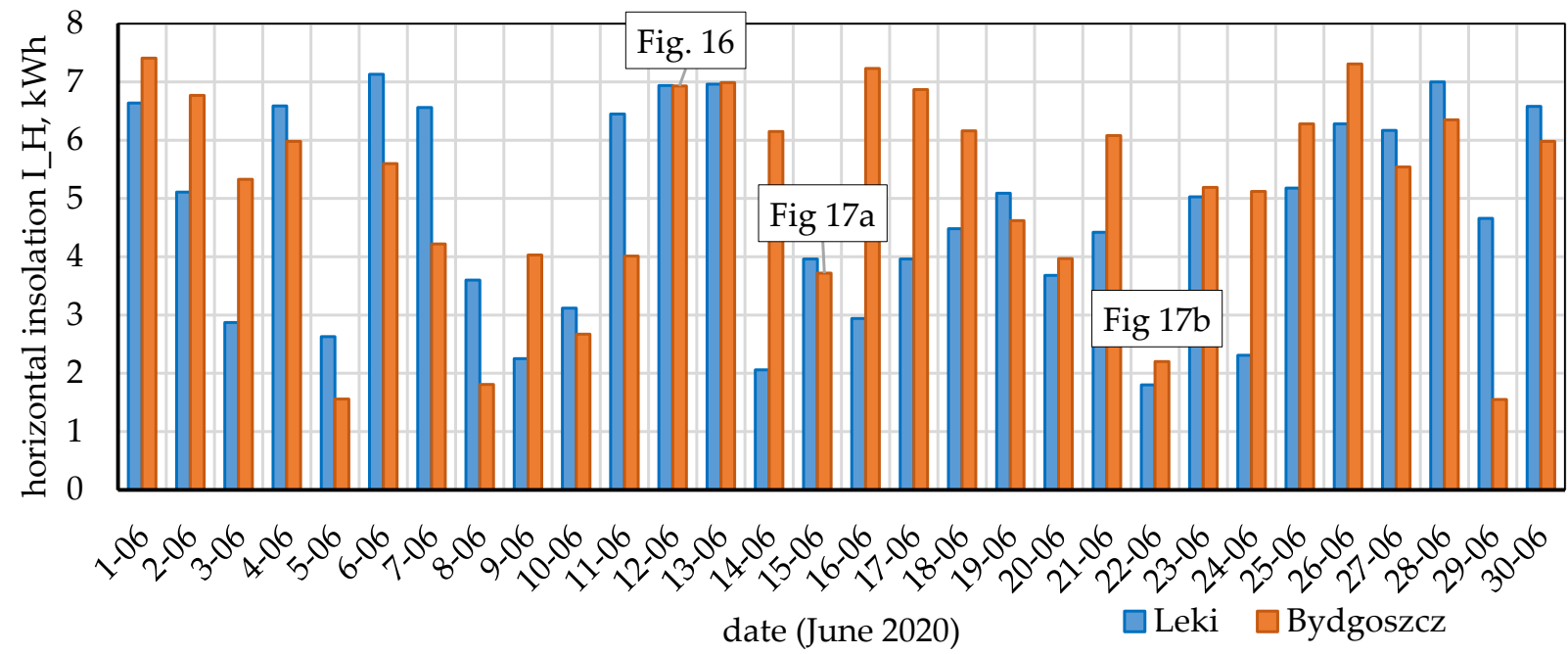

Figure 15. Comparison of insolation values for both locations for individual days in June. (References to detail figures are marked-energy production results for both installations.)

In order to compare the volume of energy production in both installations, two days were selected (Figure 16) for which high insolation was recorded in both installations, followed by days with low insolation.

On 12 and 13 June, both locations recorded comparable high levels of insolation of $7 \mathrm{kWh} / \mathrm{m}^{2} /$ day (Figure 15). On selected days, the installation in Leki produced 6.08 and $6.39 \mathrm{kWh} / \mathrm{kWp}$, respectively, and in Bydgoszcz 6.20 and $7.03 \mathrm{kWh} / \mathrm{kWp}$. In both cases, the two-sided installation generated more energy. In addition, on 13.06, the influence of a different direction of PV panel foundation was observed (SW30 for Leki, S45 for Bydgoszcz), the installation in Bydgoszcz reached the maximum hourly production of $0.87 \mathrm{kWh} / \mathrm{kWp}$ at around 1:00 p.m., while Leki $0.8 \mathrm{kWh} / \mathrm{kWp}$ in the period of 2:30 p.m. (Figure 17). 


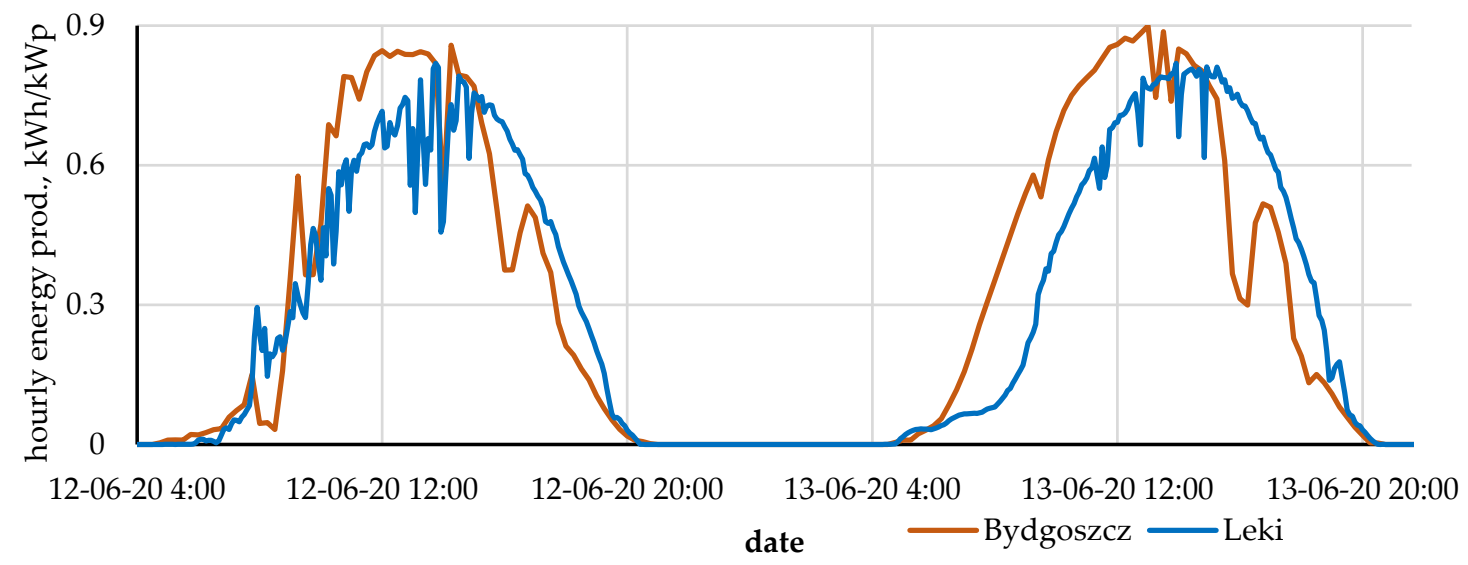

Figure 16. Comparison of the unit results of energy production from installations for 12 and 13 June.

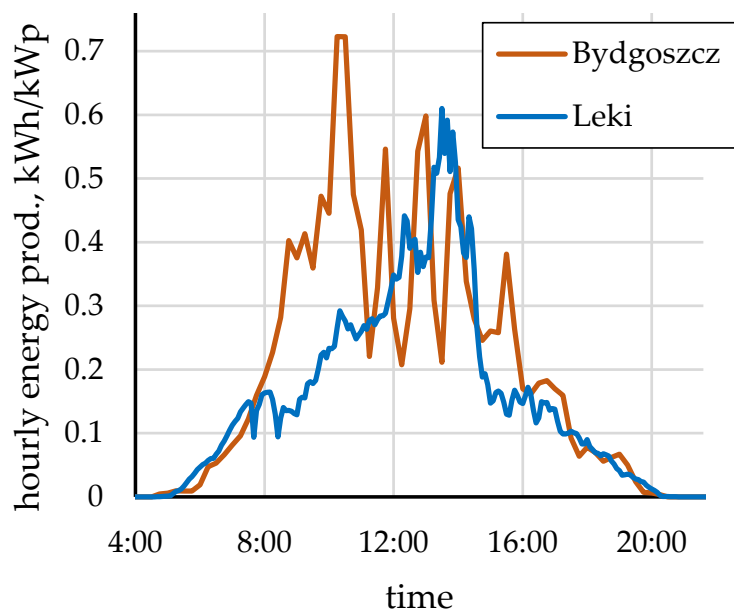

(a)

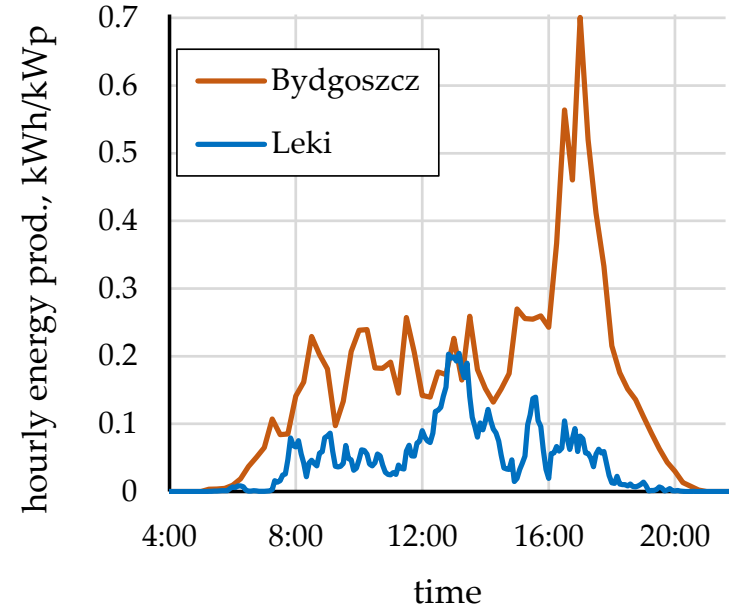

(b)

Figure 17. Comparison of the unit results of energy production in an installation, for: (a) 15 June; (b) 22 June.

On 15 and 22 June in the analysed locations, comparable low insolation was recorded (Figure 15), not greater than $4 \mathrm{kWh} / \mathrm{m}^{2} /$ day on 15 June and approx. $2 \mathrm{kWh} / \mathrm{m}^{2} /$ day on $22 \mathrm{June}$. Unit energy production on June 15 was 2.8 (Bydgoszcz) and 0.8 (Leki) $\mathrm{kWh} /(\mathrm{kWp} \cdot$ day), and 22 June, respectively, 3.6 and $2.8 \mathrm{kWh} /(\mathrm{kWp} \cdot$ day).

Analysing both cases (Figures 16 and 17), it can be seen that at lower values of insolation, two-sided panels produce more energy, which results in lower variability of the available/produced energy from bifacial PV installations compared to that of one-sided panels. That is also good for increasing direct consumption as peaks around midday are avoided and the broadening leads to longer time during the day in which electricity can be used, even more as, during midday, many people are not at home.

With comparable insolation, a bifacial installation produces approximately $10 \%$ (for high insolation) to $28 \%$ (for low insolation) more energy than a monofacial installation.

\subsection{Carbon Dioxide Emission Reduction Analyses}

The installation in Leki produced $583.87 \mathrm{kWh}$ of electricity in June and $4300 \mathrm{kWh}$ per year (Table 3); the installation in Bydgoszcz produced $828.13 \mathrm{kWh}$, and $6091 \mathrm{kWh}$ per year (Table 3). This makes it possible to avoid $\mathrm{CO}_{2}$ emissions at the level of 397 to $435 \mathrm{~kg}$ and 563 to $617 \mathrm{~kg}$, which will amount from 2.9 to $3.2 \mathrm{Mg}$ and 4.1 to $4.5 \mathrm{Mg}$ per year. 
Additionally, considering the power of the panels (Table 2), it was found that the annual energy production for Leki (monofacial panel) and Bydgoszcz (bifacial) is $853 \mathrm{kWh} / \mathrm{kWp}$ and $999 \mathrm{kWh} / \mathrm{kWp}$, respectively. Avoided annual $\mathrm{CO}_{2}$ emission in relation to the installation capacity is from 0.58 to $0.64 \mathrm{Mg} / \mathrm{kWp}$ and from 0.68 to $0.74 \mathrm{Mg} / \mathrm{kWp}$ and is on average approx. $16 \%$ higher for bifacial installations. Daily unit reduction of $\mathrm{CO}_{2}$ emissions is depicted in Figure 18.

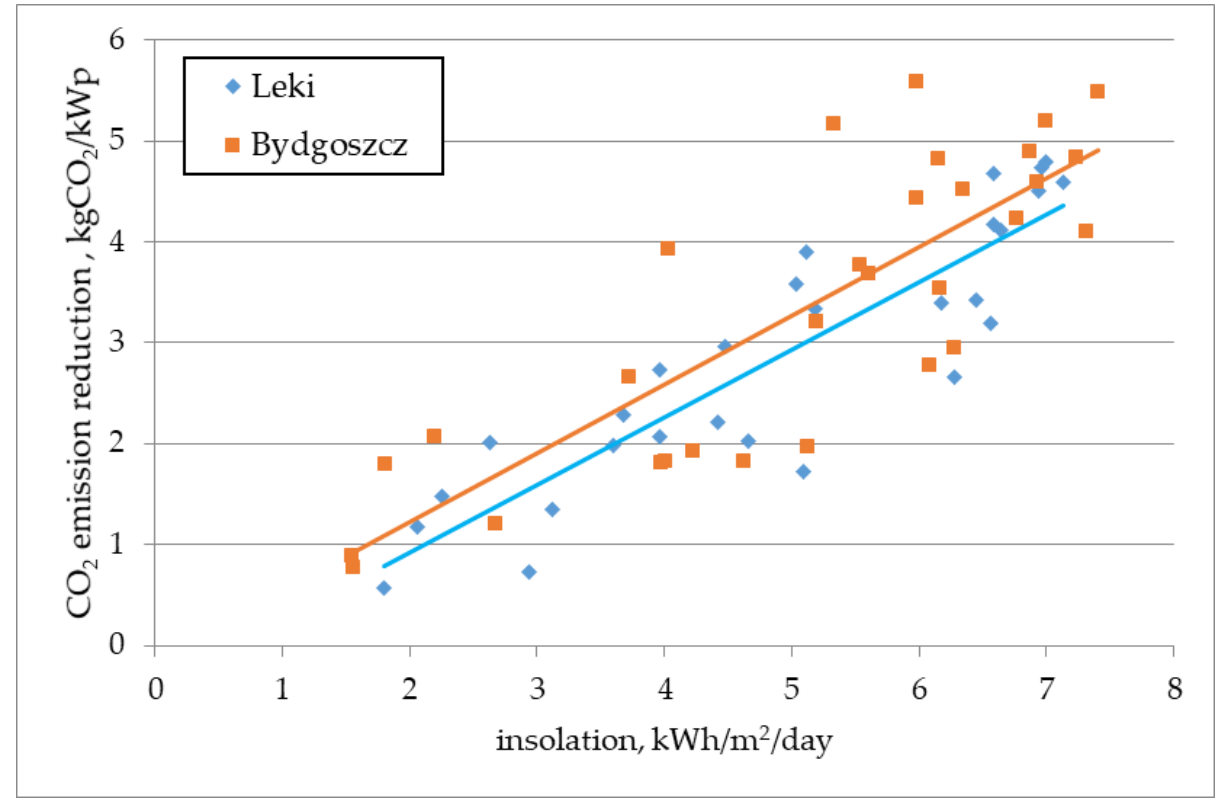

Figure 18. Daily reduction of $\mathrm{CO}_{2}$ emissions as a function of insolation.

Analysing the daily energy production (Figures 11 and 12), which is closely related to insolation (Figure 15) and assuming the $\mathrm{CO}_{2}$ emission factors for fossil fuels and the average emission factor resulting from PV production equal to $25 \mathrm{~g}_{\mathrm{CO} 2} / \mathrm{kWh}$ [58], the impact of the amount of insolation on reduction of $\mathrm{CO}_{2}$ emissions.

The results presented in Figure 18 confirm the greater efficiency of the system with the bifacial installation and the resulting higher reduction of $\mathrm{CO}_{2}$ emissions.

The cost of reducing $\mathrm{CO}_{2}$ emissions depends on the share of energy sources in the structure of its production. An exemplary emission factor for electricity generated in a gas power plant is $400 \mathrm{kgCO}_{2} / \mathrm{MWh}$, while for a coal power plant, it is $850 \mathrm{kgCO}_{2} / \mathrm{MWh}$ [59]. Forecasts for the development of the power industry in the perspective of 2060 are varied $[54,60]$. Depending on the variant depending on the costs of emission allowances, gas prices or the share of renewable energy, the share of coal energy in 2020-2040 changes from $62 \%$ to $55.7 \%$ for the variant with high costs for emission allowances from $51.6 \%$ to $13.4 \%$ for the option of reducing the emission level to 85 million $\mathrm{Mg} \mathrm{CO}_{2}$.

With the current emission indicators related to the production of panels $-25 \mathrm{~g}_{\mathrm{CO} 2} / \mathrm{kWh}$ and the indicator concerning $\mathrm{CO}_{2}$ emissions related to electricity production in Poland $765 \mathrm{gCO}_{2} / \mathrm{kWh}$, the unit cost of reducing $\mathrm{CO}_{2}$ emissions is about EUR 48 for monofacial and 110 for bifacial (without subsidies) per $\mathrm{Mg} \mathrm{CO}_{2}$, taking into account 20 years of operation of the installation (Figure 19). In the case of a decrease in the emissivity of electricity production in Poland to the level of $400 \mathrm{gCO}_{2} / \mathrm{kWh}$, the unit cost increases to approx. 93 and 210 EUR per $\mathrm{MgCO}_{\mathrm{C} 2}$. If the emission related to the production of PV panels was much higher, i.e., $85 \mathrm{~g}_{\mathrm{CO} 2} / \mathrm{kWh}$, these values would be for monofacial $52 \mathrm{EUR} / \mathrm{MgCO}_{2}$ and for bifacial 118 EUR/MgCO2, respectively. Considering the subsidy, these values are correspondingly lower (Figure 20). 


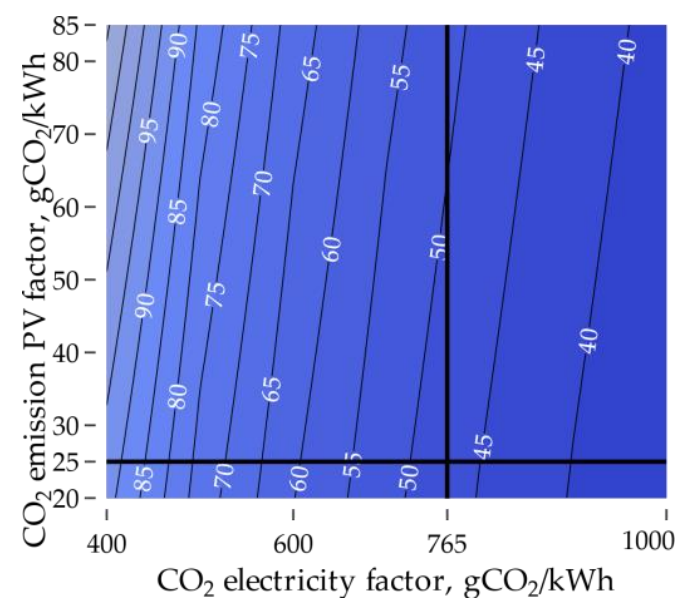

(a)

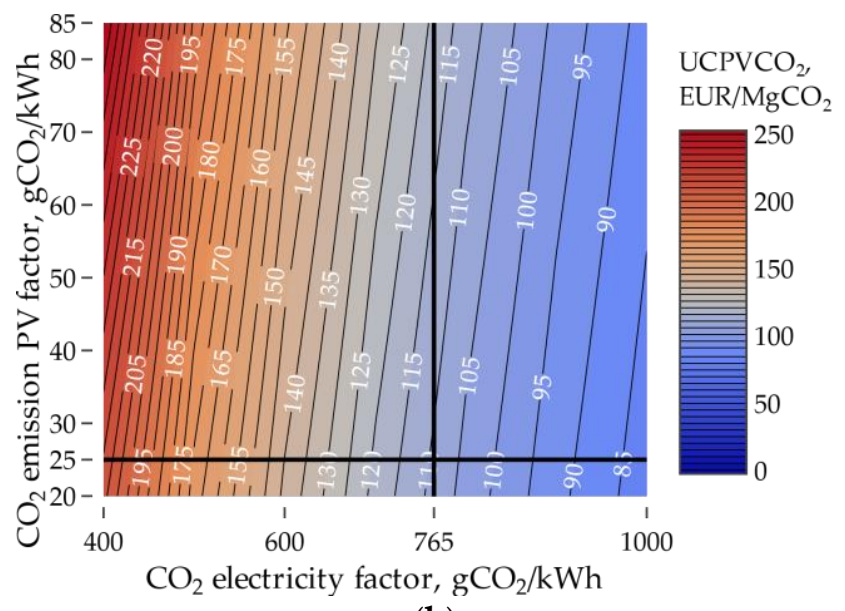

(b)

Figure 19. Unit (investment) cost of $\mathrm{CO}_{2}$ emission reduction as a function of $\mathrm{CO}_{2}$ emission factor in the national grid and emissions related to the production of panels: (a) Leki; (b) Bydgoszcz.

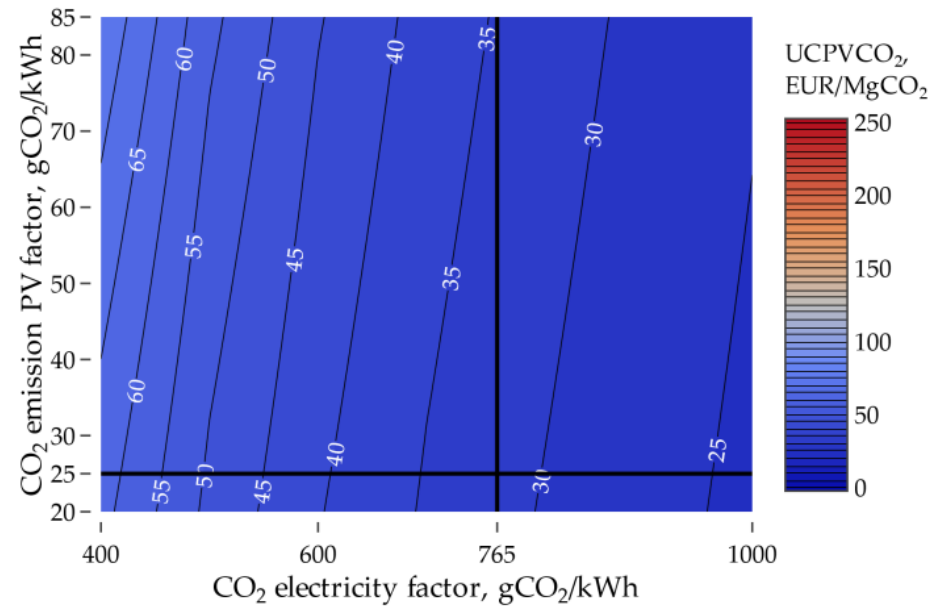

Figure 20. Unit (investment) cost of $\mathrm{CO}_{2}$ emission reduction as a function of $\mathrm{CO}_{2}$ emission factor in the national grid and emissions related to the production of Leki panels with subsidy.

\subsection{Profitability Analyses}

The results of the NPV analysis are presented in Figure 21. In addition, the NPV for Leki and NPV for Bydgoszcz (diff.NPV_Equation (11)) were determined differently (Figure 22a) and similarly, taking into account the subsidies for the Leki installation (Figure 22b).

Figure 22 shows under which economic conditions the bifacial panel's price reaches (Bydgoszcz case) a higher NPV than the monofacial PV panels (Leki case). As can be seen in Figure 22a, the installation in Bydgoszcz does not give a greater result in the form of NPV. Considering the subsidy in the scope of electricity price $0.1-0.2 \mathrm{EUR} / \mathrm{kWh}$, the installation in Bydgoszcz is also in no case more profitable.

For ElP $=0.15 \mathrm{EUR} / \mathrm{kWh}$ and $r=0 \%$, unit NPV for monofacial is equal $1200 \mathrm{EUR} / \mathrm{kWp}$, and for bifacial $1060 \mathrm{EUR} / \mathrm{kWp}$. The difference of EUR 140/kWp is increased to EUR $410 / \mathrm{kWp}$ if the subsidy "My electricity" is taken into account. 


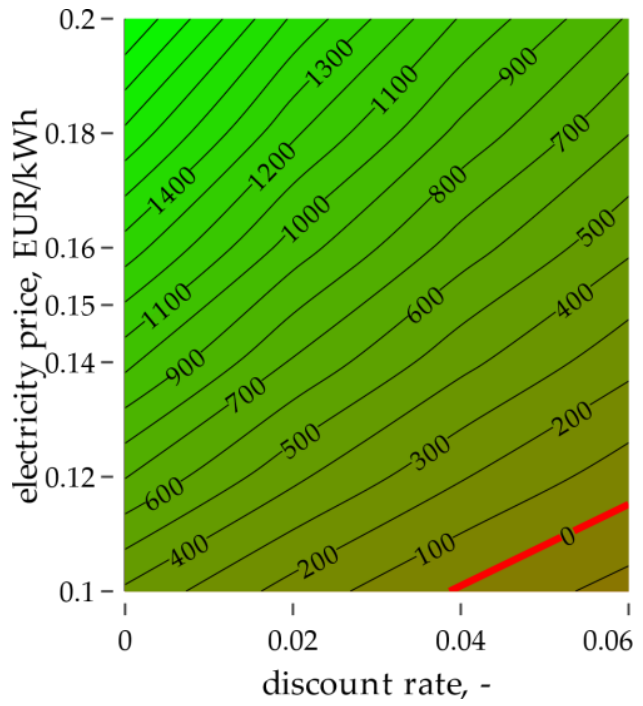

(a)

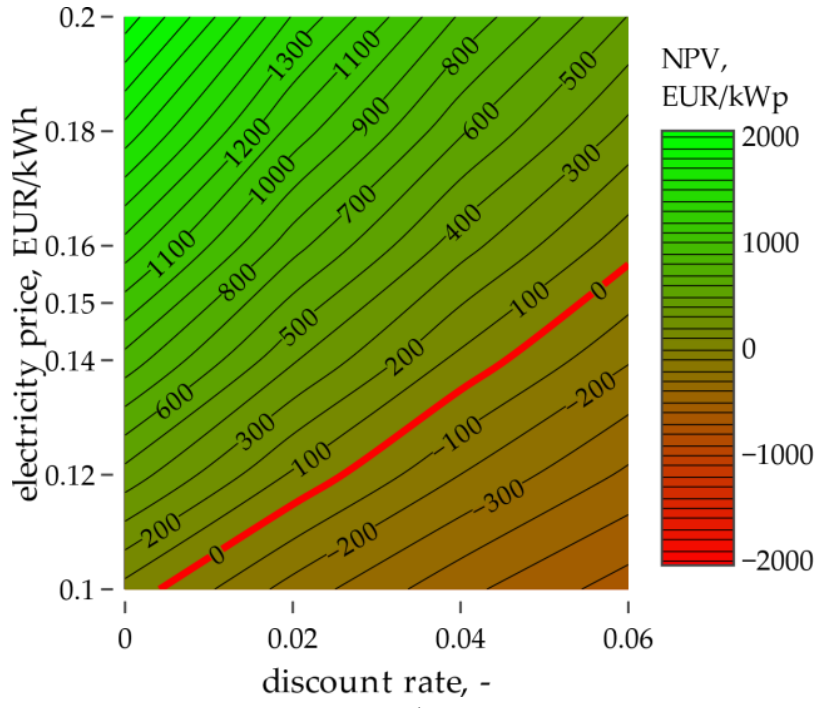

(b)

Figure 21. Net Present Value (NPV) as a function of electricity price and discount rate value: (a) for Leki; (b) for Bydgoszcz. $\mathrm{ElP}=0.15 \mathrm{EUR} / \mathrm{kWh}$ is actual electricity price in Poland.

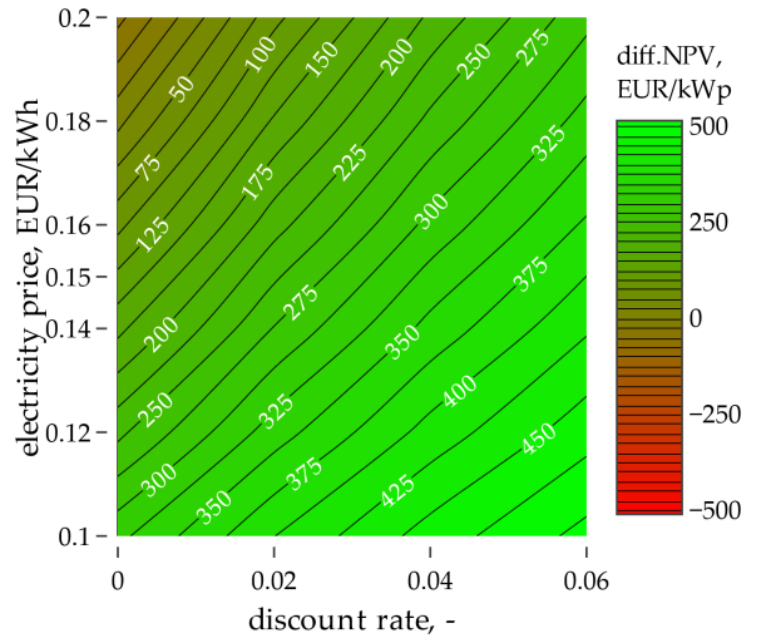

(a)

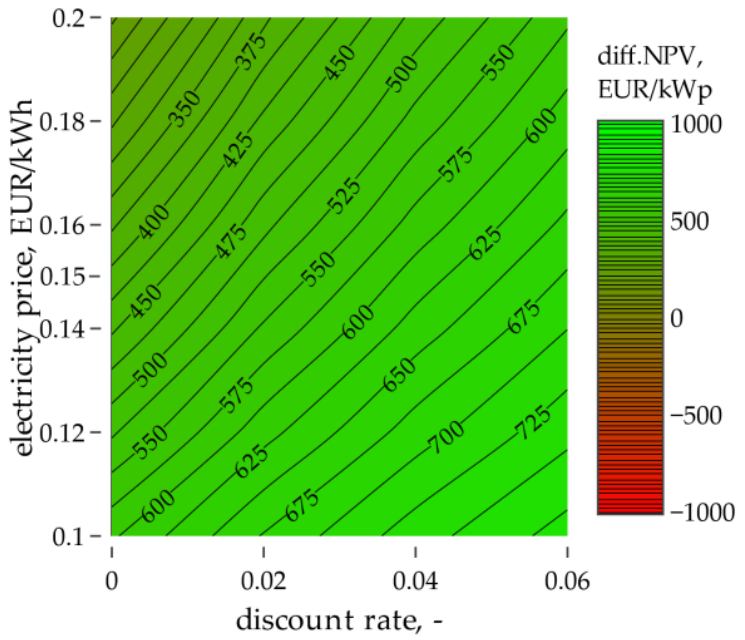

(b)

Figure 22. Difference of Net Present Value (diff.NPV) Leki-Bydgoszcz as a function of electricity price and discount rate value: (a) excluding subsidies; (b) including subsidies. ElP $=0.15 \mathrm{EUR} / \mathrm{kWh}$ is actual electricity price in Poland.

\section{Conclusions}

There are more and more PV installations in Poland, especially microinstallations (up to $50 \mathrm{kWp}$, but due to the regulations of the Prosument and "My Electricity", the majority of microinstallations in Poland is up to $10 \mathrm{kWp}$.). In 2017, 12,900 microinstallations were installed, in 2018-27,300, and in 2019-104,000 (mostly up to $10 \mathrm{kWp)} \mathrm{[61].}$

Typical installations used in Poland are systems with monofacial modules; bifacial installations in Poland are practically nonexistent. The work analyses the economics and ecology of operation of such microinstallations in two localization Bydgoszcz and Leki (near Tarnow). The analysis was performed for similar insolation conditions. Bifacial installations produce approx. from $10 \%$ for high insolation to $28 \%$ for low insolation more energy than a monofacial installation. Therefore, they enable greater reductions in $\mathrm{CO}_{2}$ emissions. 
In Poland, the share of fossil fuels (hard coal and lignite) in electricity generation is of importance, which gives the $\mathrm{CO}_{2}$ footprint of $765 \mathrm{~g}_{\mathrm{CO} 2} / \mathrm{kWh}$. The production of one kWh of energy from PV theoretically limits this value, but it practically replaces the most emitting carbon sources. In the analysed cases the annual reduction of $\mathrm{CO}_{2}$ emissions, taking the emissions resulting from the production of panels into account, could be from 0.58 to $0.64 \mathrm{Mg} / \mathrm{kWp}$ for monofacial PV and 0.68 to $0.74 \mathrm{Mg} / \mathrm{kWp}$ for bifacial PV. Avoided $\mathrm{CO}_{2}$ emission is on average approximately $16 \%$ higher for bifacial installations.

Spending 1 Euro for PV installations contributes to emission savings of $20.8 \mathrm{~kg}_{\mathrm{CO} 2}$ (for $25 \mathrm{~g}_{\mathrm{CO} 2} / \mathrm{kWh}$ as environmental cost of PV installation) in the case of monofacial panels and in the case of bifacial panels to $9 \mathrm{~kg}_{\mathrm{CO} 2}$.

The installation subsidised under the "My Electricity" program can reach an NPV of EUR 6000 over 20 years with a discount rate $r=0$ and assuming an electricity price of $0.15 \mathrm{EUR} / \mathrm{kWh}$. If this price is increased to $0.2 \mathrm{EUR} / \mathrm{kWh}, \mathrm{NPV}$ will be 10,000 EUR.

Author Contributions: Conceptualization, P.O., D.M. and M.O.; methodology, P.O. and M.O.; software, P.O., and D.M.; validation, M.O.; formal analysis, P.O., D.M. and M.O.; investigation, M.O.; resources, P.O. and T.M.; data curation, P.O., T.M. and M.O.; writing-original draft preparation, P.O., D.M., and M.O.; writing—review and editing, M.O., D.M. and A.D.; visualization, P.O. and M.O.; supervision, P.O.; project administration, P.O. and M.O.; funding acquisition, P.O. and A.D. All authors have read and agreed to the published version of the manuscript.

Funding: There is no external funding.

Institutional Review Board Statement: Not applicable.

Informed Consent Statement: Not applicable.

Data Availability Statement: Not applicable.

Conflicts of Interest: The authors declare no conflict of interest.

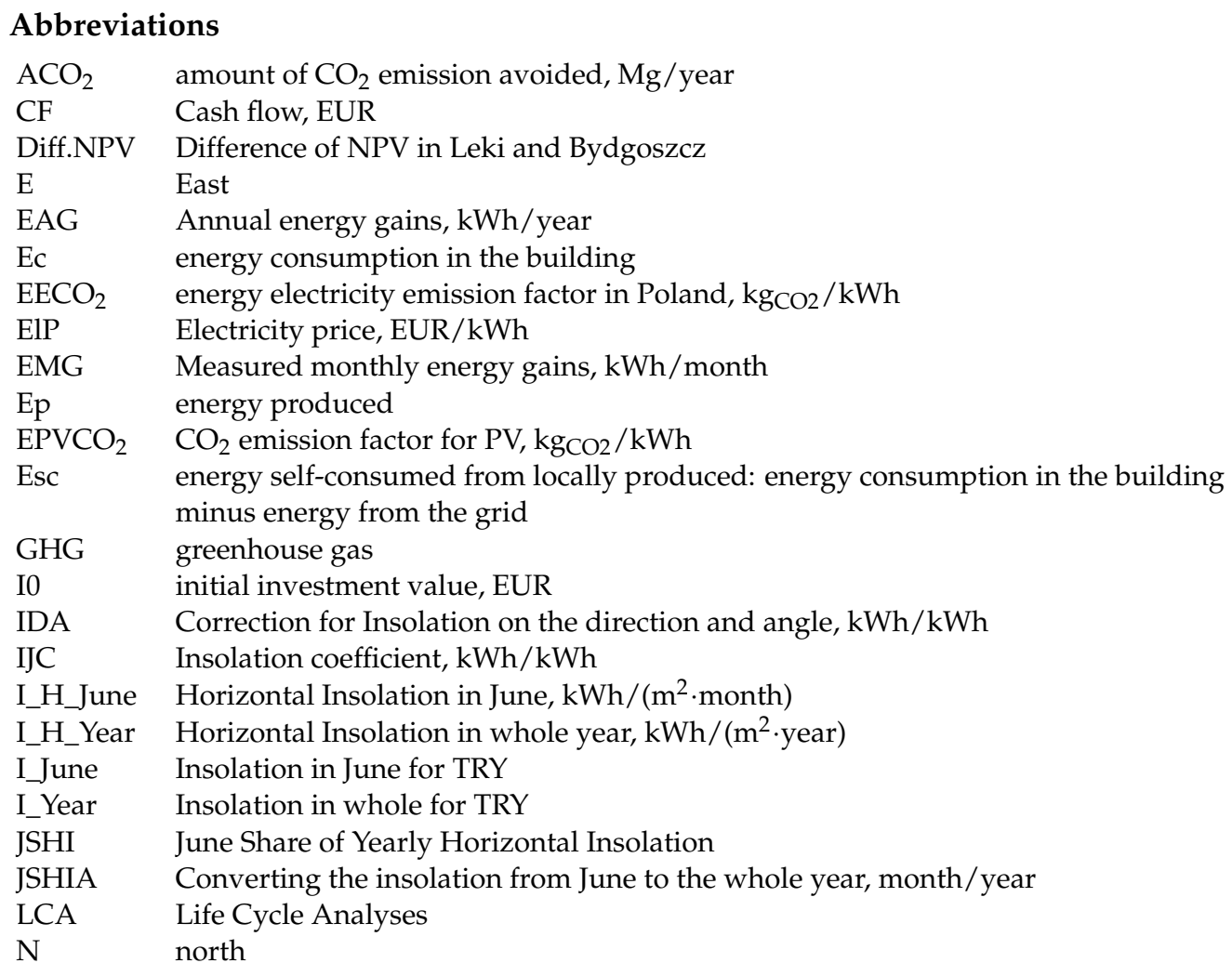




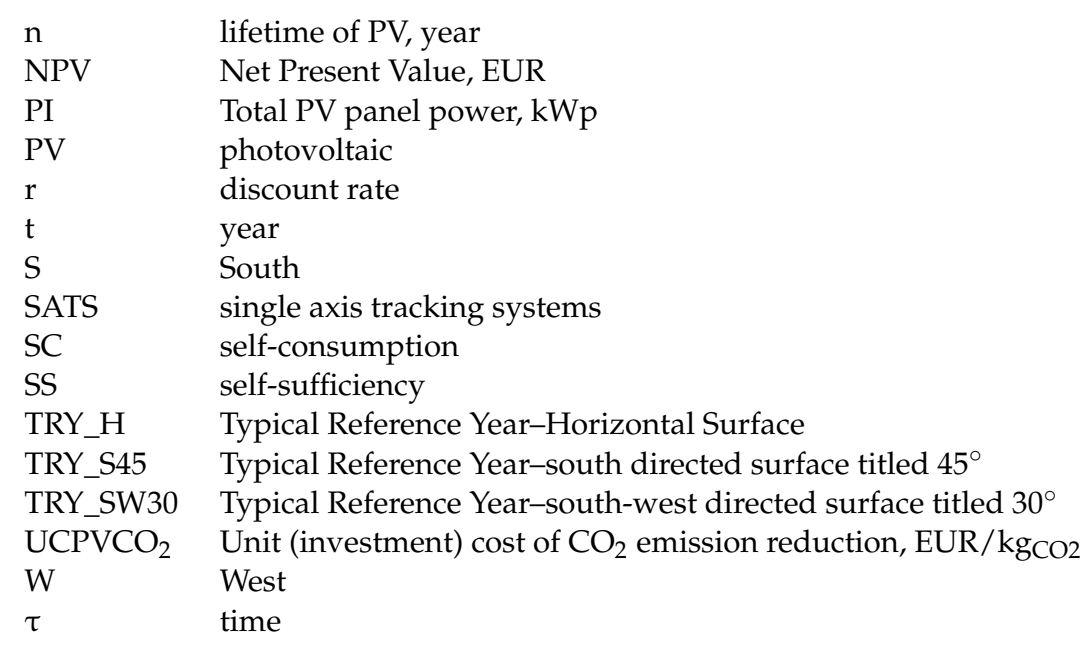

\section{References}

1. Pestana, D.G.; Rodrigues, S.; Morgado-Dias, F. Environmental and economic analysis of solar systems in Madeira, Portugal. Util. Policy 2018, 55, 31-40. [CrossRef]

2. Peng, J.; Lu, L.; Yang, H. Review on life cycle assessment of energy payback and greenhouse gas emission of solar photovoltaic systems. Renew. Sustain. Energy Rev. 2013, 19, 255-274. [CrossRef]

3. National Centre for Emissions Management. $\mathrm{CO}_{2}, \mathrm{SO}_{2}, \mathrm{NOx}, \mathrm{CO}$ and Total Dust EMISSION RATIOS FOR ELECTRICITY Based on the Information Contained in the National Database of Greenhouse Gas Emissions and other Substances for 2018. Available online: https://www.kobize.pl/uploads/materialy/materialy_do_pobrania/wskazniki_emisyjnosci/Wskazniki_emisyjnosci_ grudzien_2019.pdf (accessed on 7 April 2020).

4. Sampaio, P.G.V.; González, M.O.A. Photovoltaic solar energy: Conceptual framework. Renew. Sustain. Energy Rev. 2017, 74, 590-601. [CrossRef]

5. European Commission. A Clean Planet for All. A European Long-Term Strategic Vision for a Prosperous, Modern, Competitive and Climate Neutral Economy; EUR-Lex: Brussels, Belgium, 2018.

6. Jaeger-Waldau, A. PV Status Report 2019; Publications Office of the European Union: Brussels, Belgium, 2019.

7. Jäger-Waldau, A.; Kougias, I.; Taylor, N.; Thiel, C. How photovoltaics can contribute to GHG emission reductions of $55 \%$ in the EU by 2030. Renew. Sustain. Energy Rev. 2020, 126, 109836. [CrossRef]

8. Micheli, D.; Alessandrini, S.; Radu, R.; Casula, I. Analysis of the outdoor performance and efficiency of two grid connected photovoltaic systems in northern Italy. Energy Convers. Manag. 2014, 80, 436-445. [CrossRef]

9. Phinikarides, A.; Makrides, G.; Zinsser, B.; Schubert, M.; Georghiou, G.E. Analysis of photovoltaic system performance time series: Seasonality and performance loss. Renew. Energy 2015, 77, 51-63. [CrossRef]

10. Zdyb, A.; Gulkowski, S. Performance assessment of four different photovoltaic technologies in Poland. Energies 2020, 13, 196. [CrossRef]

11. Global solar Atlas GHI—Global Horizontal Irradiation. Available online: http://solargis.info/doc/_pics/freemaps/1000px/ghi/ SolarGIS-Solar-map-Europe-en.png (accessed on 12 November 2020).

12. Olczak, P.; Matuszewska, D.; Zabagło, J. The Comparison of Solar Energy Gaining Effectiveness between Flat Plate Collectors and Evacuated Tube Collectors with Heat Pipe: Case Study. Energies 2020, 13, 1829. [CrossRef]

13. Chwieduk, D.; Chwieduk, M. Determination of the Energy Performance of a Solar Low Energy House with Regard to Aspects of Energy Efficiency and Smartness of the House. Energies 2020, 13, 3232. [CrossRef]

14. Olczak, P.; Kryzia, D.; Matuszewska, D.; Kuta, M. “My Electricity” Program Effectiveness Supporting the Development of PV Installation in Poland. Energies 2021, 14, 231. [CrossRef]

15. Rynek-Elektryczny W Czerwcu moc Zainstalowana Fotowoltaiki Przekroczyła 2 GW. Available online: https://www rynekelektryczny.pl/moc-zainstalowana-fotowoltaiki-w-polsce/ (accessed on 15 July 2020).

16. Olczak, P.; Matuszewska, D.; Kryzia, D. "Mój Prąd" as an example of the photovoltaic one off grant program in Poland. Energy Policy J. 2020, 23, 123-138. [CrossRef]

17. Szczerbowski, R.; Kornobis, D. The proposal of an energy mix in the context of changes in Poland's energy policy. Polityka Energetyczna 2019, 22, 5-18. [CrossRef]

18. Ministry of Development Typical Reference Year. Available online: https://www.gov.pl/web/fundusze-regiony/dane-doobliczen-energetycznych-budynkow (accessed on 18 December 2019).

19. NFOŚiGW Mój Prąd. Available online: https:/ / mojprad.gov.pl/wyniki-1-naboru-2019/ (accessed on 7 April 2020).

20. Almeshaiei, E.; Al-Habaibeh, A.; Shakmak, B. Rapid evaluation of micro-scale photovoltaic solar energy systems using empirical methods combined with deep learning neural networks to support systems' manufacturers. J. Clean. Prod. 2020, $244,118788$. [CrossRef] 
21. Bukowski, M.; Majewski, J.; Sobolewska, A. Macroeconomic Electric Energy Production Efficiency of Photovoltaic Panels in Single-Family Homes in Poland. Energies 2021, 14, 126. [CrossRef]

22. Guta, D.D. Determinants of household adoption of solar energy technology in rural Ethiopia. J. Clean. Prod. 2018, 204, 193-204. [CrossRef]

23. Komorowska, A.; Kamiński, J. A review of the 2018 Polish capacity market auctions. Energy Policy J. 2019, 22, 75-88. [CrossRef]

24. Paska, J.; Surma, T.; Terlikowski, P.; Zagrajek, K. Electricity generation from renewable energy sources in Poland as a part of commitment to the polish and EU energy policy. Energies 2020, 13, 4261. [CrossRef]

25. Elshurafa, A.M.; Albardi, S.R.; Bigerna, S.; Bollino, C.A. Estimating the learning curve of solar PV balance-of-system for over 20 countries: Implications and policy recommendations. J. Clean. Prod. 2018, 196, 122-134. [CrossRef]

26. IEO. PV MARKET IN POLAND 2020; IEO: Warsaw, Poland, 2020.

27. Szczerbowski, R. Energy security of Poland-Energy mix and energy efficiency. Polityka Energetyczna 2013, 16, 35-47.

28. Matuszewska, D.; Kuta, M.; Olczak, P. Techno-Economic Assessment of Mobilized Thermal Energy Storage System Using Geothermal Source in Polish Conditions. Energies 2020, 13, 3404. [CrossRef]

29. Zelazna, A.; Gołębiowska, J.; Zdyb, A.; Pawłowski, A. A hybrid vs. on-grid photovoltaic system: Multicriteria analysis of environmental, economic, and technical aspects in life cycle perspective. Energies 2020, 13, 3978. [CrossRef]

30. Mirowski, T.; Sornek, K. Potential of prosumer power engineering in Poland by example of micro PV installation in private construction. Energy Policy J. 2015, 18, 73-84.

31. Pepłowska, M.; Olczak, P. The tilt angle selecting problem of PV panels taking the energy demand profile into account. Bull. Miner. Energy Econ. Res. Inst. Pol. Acad. Sci. 2018, 102, 91-100.

32. Poland, O. Data of Electricity Distribution System Operators; Data direct from DSO; Unpublished work; 2020.

33. NASA Solar Radiation. Available online: https:/ / power.larc.nasa.gov/data-access-viewer/ (accessed on 20 July 2020 ).

34. Ren, F.R.; Tian, Z.; Liu, J.; Shen, Y.T. Analysis of $\mathrm{CO}_{2}$ emission reduction contribution and efficiency of China's solar photovoltaic industry: Based on Input-output perspective. Energy 2020, 199, 117493. [CrossRef]

35. Louwen, A.; Van Sark, W.G.; Faaij, A.P.C.; Schropp, R.E.I. Re-assessment of net energy production and greenhouse gas emissions avoidance after 40 years of photovoltaics development. Nat. Commun. 2016, 7, 13728. [CrossRef] [PubMed]

36. Mohammadi, K.; Naderi, M.; Saghafifar, M. Economic feasibility of developing grid-connected photovoltaic plants in the southern coast of Iran. Energy 2018, 156, 17-31. [CrossRef]

37. Antonanzas, J.; Arbeloa-Ibero, M.; Quinn, J.C. Comparative life cycle assessment of fixed and single axis tracking systems for photovoltaics. J. Clean. Prod. 2019, 240, 118016. [CrossRef]

38. Frischknecht, R.; Itten, R.; Sinha, P.; de Wild-Scholten, M.; Zhang, J.; Fthenakis, V.; Kim, H.C.; Raugei, M.; Stucki, M. Life Cycle Inventories and Life Cycle Assessments of Photovoltaic Systems. PVPS Task 12, Report T12-04:2015; IEA: Paris, France, 2015.

39. Nugent, D.; Sovacool, B.K. Assessing the lifecycle greenhouse gas emissions from solar PV and wind energy: A critical metasurvey. Energy Policy 2014, 65, 229-244. [CrossRef]

40. Prăvălie, R.; Bandoc, G. Nuclear energy: Between global electricity demand, worldwide decarbonisation imperativeness, and planetary environmental implications. J. Environ. Manag. 2018, 209, 81-92. [CrossRef]

41. Park, H.; Chang, S.; Park, S.; Kim, W.K. Outdoor performance test of bifacial n-type silicon photovoltaic modules. Sustainability 2019, 11, 6234. [CrossRef]

42. Mirowski, T.; Pepłowska, M. Simulation Analysis of Electricity Consumption for the Final Consumer with the Use of Smart Metering. Energy Policy J. 2016, 2, 81-91.

43. Kryzia, D.; Kuta, M.; Matuszewska, D.; Olczak, P. Analysis of the potential for gas micro-cogeneration development in Poland using the Monte Carlo method. Energies 2020, 13, 3140. [CrossRef]

44. Rodríguez-Gallegos, C.D.; Bieri, M.; Gandhi, O.; Singh, J.P.; Reindl, T.; Panda, S.K. Monofacial vs bifacial Si-based PV modules: Which one is more cost-effective? Sol. Energy 2018, 176, 412-438. [CrossRef]

45. Reich, N.H.; Alsema, E.A.; Van Sark, W.G.; Turkenburg, W.C.; Sinke, W.C. Greenhouse gas emissions associated with photovoltaic electricity from crystalline silicon modules under various energy supply options. Prog. Photovolt. Res. Appl. 2011, 19, 603-613. [CrossRef]

46. Gazbour, N.; Razongles, G.; Schaeffer, C.; Charbuillet, C. Photovoltaic power goes green. In Proceedings of the 2016 Electronics Goes Green 2016+, EGG 2016, Berlin, Germany, 6-9 September 2016.

47. Olczak, P.; Pepłowska, M. Problematyka doboru wielkości przydomowych instalacji fotowoltaicznych. In Energetyka Solarna; Foundation for Clean Energy: Poznan, Poland, 2018; pp. 80-90.

48. Hanplast-Energy SW PREMIUM BIFACIAL (HJT). Available online: http:/ /hanplast.energy /uploads / files/GWARANCJEHP/ KARTATECHNICZNA-HanplastSWPremiumBifacialHJTEN3053103155-6mmv01.10.2019.pdf (accessed on 18 July 2020).

49. Longi LR4-60HPH 360M. Available online: https:/ / en.longi-solar.com/uploads/attach/20200423/5ea0f91d33235.pdf (accessed on 2 June 2020).

50. Canales, F.A.; Jadwiszczak, P.; Jurasz, J.; Wdowikowski, M.; Ciapała, B.; Kaźmierczak, B. The impact of long-term changes in air temperature on renewable energy in Poland. Sci. Total Environ. 2020, 729, 138965. [CrossRef]

51. Olek, M.; Olczak, P.; Kryzia, D. The sizes of Flat Plate and Evacuated Tube Collectors with Heat Pipe area as a function of the share of solar system in the heat demand. E3S Web Conf. 2016, 10, 00139. [CrossRef] 
52. Olczak, P.; Kryzia, D.; Pepłowska, M.; Olek, M. Influence of Inclination Angle and its Adjustment Time on Insolation of Collector or Photovoltaic Panel. Dist. Heat. Vent. 2018, 49, 506-509.

53. Olczak, P.; Kryzia, D.; Augustyn, A.; Olek, M. The economic profitability of the changing size of solar collectors surface in the case study of the household domestic hot water installation. Bull. Miner. Energy Econ. Res. Inst. Pol. Acad. Sci. 2018, 102, 77-90.

54. Olczak, P.; Olek, M.; Kryzia, D. The ecological impact of using photothermal and photovoltaic installations for DHW preparation. Polityka Energetyczna 2020, 23, 65-74. [CrossRef]

55. Kryzia, D.; Kopacz, M.; Kryzia, K. The Valuation of the Operational Flexibility of the Energy Investment Project Based on a Gas-Fired Power Plant. Energies 2020, 13, 1567. [CrossRef]

56. CSO. Energy Consumption in Households in 2018; Central Statistical Office: Warsaw, Poland, 2019.

57. Copernicus Climate Change Service (C3S). ERA5: Fifth Generation of ECMWF Atmospheric Reanalyses of the Global Climate. Copernicus Climate Change Service Climate Data Store (CDS). 2017. Available online: https://cds.climate.copernicus.eu/ cdsapp\#!/home (accessed on 4 November 2020).

58. Kommalapati, R.; Kadiyala, A.; Shahriar, M.T.; Huque, Z. Review of the life cycle greenhouse gas emissions from different photovoltaic and concentrating solar power electricity generation systems. Energies 2017, 10, 350. [CrossRef]

59. PARP. Conversion Guidelines-Greenhouse Gas Emissions. Available online: https://www.parp.gov.pl/storage/grants/ documents /105/Wytyczne-dotyczce-konwersji---emisje-gazw-cieplarnianych_20200225.pdf (accessed on 28 July 2020).

60. Kprm Model of the Optimum Energy Mix for Poland until 2060. Available online: https://www.premier.gov.pl/files/files/ energymix_das_dost.pdf (accessed on 28 July 2020).

61. Globenergia over 104,000 PV Micro-Installations in 2019! Available online: https://globenergia.pl/ponad-104-tysiacemikroinstalacji-pv-w-2019-roku-gigantyczny-wzrost-w-fotowoltaice/ (accessed on 24 July 2020). 